\title{
Triadimefon in aquatic environments: occurrence, fate, toxicity, and ecological risk
}

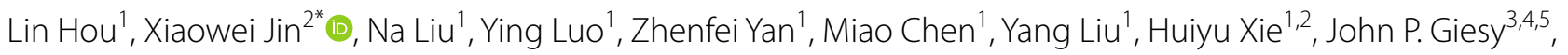
Fengchang $\mathrm{Wu}^{1}$ and Jian $\mathrm{Xu}^{1 *}$

\begin{abstract}
Background: As a triazole fungicide, triadimefon is widely used around the world. The ubiquitous occurrence of triadimefon in aquatic environments and potential adverse effects on aquatic organisms have resulted in global concerns. In this review, the current state of knowledge on occurrence, environmental behavior, and toxic effects are presented and used to conduct an assessment of risks posed by current concentrations of triadimefon in aquatic environments.
\end{abstract}

Results: The key findings from this review are that: (1) triadimefon occurred widely in surface waters, with high rates of detection; (2) abiotic degradation of triadimefon was affected by many factors. Stereoselectivity was found during biotic degradation and metabolism of triadimefon. Different enantiomers can cause various adverse effects, which complicates the assessment and requires enantiomers-specific considerations; (3) triadimefon exposure can affect organisms by causing multiple toxic effects on the thyroid, reproductive system, liver, nervous system as well as carcinogenicity and teratogenicity, and it can also act synergistically with other pesticides. Long-term, low-dose effects were considered to be the main characteristics of toxic effects of triadimefon; (4) results of the risk assessment based on probabilistic relationships represented by joint probability curves (JPCS) indicated that risk of triadimefon was classified as low risk.

Conclusion: Triadimefon occurred widely in surface waters, with high rates of detection, while the concentration data of triadimefon in surface water is insufficient. Researches about toxic effects and mechanisms of triadimefon on invertebrate are needed. Meanwhile, researches about toxic effects and environmental exposure of chiral monomers are also required. Due to its reproductive toxicity, triadimefon might result in adverse effects on the population level or even on the ecosystem level. Risk assessments for pesticides that cause long-term and low-dose effects on aquatic organisms such as triadimefon need to consider higher-level ecological risk.

Keywords: Triadimefon, Pollution characteristics, Reproductive fitness, Toxic mechanisms, Ecological risk assessment

\footnotetext{
*Correspondence: jinxw@cnemc.cn; xujian@craes.org.cn

1 State Key Laboratory of Environmental Criteria and Risk Assessment,

Chinese Research Academy of Environmental Sciences, Beijing 100012, China

${ }^{2}$ China National Environmental Monitoring Centre, Beijing 100012, China

Full list of author information is available at the end of the article
}

\section{Background}

Beginning in the 1970s, triazole fungicides have been widely used and their use has been rapidly increasing in the world. They are now the most widely used of chiral fungicides in the world. Due to the broad spectrum of activity, high quality, fast bactericidal speed, long-lasting duration of effect, strong absorption and conduction, triazole fungicides were widely used in wheat, corn, fruits, vegetables, flowers, and other crops to control rust, powdery mildew and regulation of plant growth [1]. In 2014, triazole fungicides accounted for $21.20 \%$ of the global

\section{Springer Open}

(c) The Author(s) 2022. Open Access This article is licensed under a Creative Commons Attribution 4.0 International License, which permits use, sharing, adaptation, distribution and reproduction in any medium or format, as long as you give appropriate credit to the original author(s) and the source, provide a link to the Creative Commons licence, and indicate if changes were made. The images or other third party material in this article are included in the article's Creative Commons licence, unless indicated otherwise in a credit line to the material. If material is not included in the article's Creative Commons licence and your intended use is not permitted by statutory regulation or exceeds the permitted use, you will need to obtain permission directly from the copyright holder. To view a copy of this licence, visit http://creativecommons.org/licenses/by/4.0/. 
market share for sales of fungicides, ranking second in the world. At present, there are 31 kinds of commercial triazole fungicides, among which triadimefon [1-(4-chlorophenoxy)-3, 3-dimethyl-1-(1, 2, 4-triazol-1-1) butan-2one; CAS 43121-43-3] is typical. Triadimefon has a global consumption accounting for more than $30 \%$ of all triazole fungicides [2]. Due to the extremely low effective utilization rate of pesticides [3], amounts of residual triadimefon have entered into the environments. After being absorbed and desorbed on soil, it can enter surface water and groundwater through rainwater runoff and leaching, causing water environment pollution. By using an exposure analysis model, the US Environmental Protection Agency (US EPA) estimated the expected environmental concentration of triadimefon in surface water to be $41 \mu \mathrm{g} / \mathrm{L}$ [4]. Triadimefon was also detected in the Jiulongjiang River, Tai Lake, Baiyang Lake, and other places in China, with the highest detectable concentration of $12 \mu \mathrm{g} / \mathrm{L}$ [5-8]. At the same time, on account of its strong stability, good mobility and adsorption, and long-lasting accumulation in aquatic environments, triadimefon can accumulate in bodies of aquatic organisms where it can undergo biotransformation. Exposures of various types and life stages of aquatic organisms to various concentrations of triadimefon can result in a wide range of toxic effects that poses threats to ecosystems, eventually affecting ecosystem services that can in turn affect health and economic well-being of humans.

Triadimefon has attracted extensive international attention. In 1999, the US "Safe Water Reference and Toxicity Enforcement Act (Proposition 65)" added triadimefon to the list of chemicals, the concentrations of which were controlled in drinking water. Triadimefon was thought to induce developmental toxicity, and androgen-like and estrogen-like effects [9]. In 2006, the European Union (EU) included triadimefon and transformation products on the list of pesticides with endocrinereproductive interference toxicity [10]. It is controversial whether triadimefon is an endocrine disruptor or not, but most studies showed that triadimefon caused endocrinedisrupting effects and could affect the balance of hormones in the body of animals [11-13]. According to the World Wide Fund for Nature and World Wildlife Fund (WWF), triadimefon is an estrogen receptor agonist, which had certain effects on estrogen in vitro. Regardless, its potential toxic potencies cannot be ignored. Results of several studies have demonstrated that triadimefon affected development $[12,14,15]$, reproduction $[16,17]$ of organisms and caused neurotoxicity [18], hepatotoxicity [19], cardiovascular toxicity [20] and oxidative stress $[11,13]$. In addition, triadimefon resulted in malformations of branchial arches in developing amphibians [21] or adversely affected the development of embryos of zebrafish (Danio rerio) [22]. Several previous studies have demonstrated that triadimefon altered the expressions of genes related to the hypothalamic-pituitary-thyroid axis (HPT) and disrupted thyroid endocrine function by delaying thyroid hormone-dependent metamorphic development [12]. Those results confirmed that the use of pesticides was one of the major factors in declines of populations of some amphibians [12]. In recent years, studies demonstrating the effects of triadimefon on endocrine function and oxidative stress in vertebrates have been increasing. The results have shown that triadimefon can cause oxidative stress and interfere with the endocrine system, eventually influencing reproduction [11, $15,23]$. Therefore, the long-term effect of triadimefon on aquatic ecosystems is worthy of attention. As for assessment of risks studies, Liu et al. (2018) [24] estimated the PNEC based on the reproductive fitness of triadimefon and calculated hazard quotients (HQs), which confirmed the risk of triadimefon on reproductive function. Based on the results summarized above, it is believed that more surface water concentration and toxicity data are needed for more advanced risk assessment.

Over the past few years, several studies have summarized detailed information on concentrations and toxic effects of triadimefon [20,24]. However, there has been no systematic review of the current state of knowledge regarding the presence, environmental behavior, toxic effects and potencies or a critical assessment of risks posed by triadimefon in aquatic environments. This review summarized the results of research that have been conducted on triadimefon. In the present synthetic review, environmental behavior, toxic effects and ecological risk assessment of various concentrations of triadimefon in surface waters from 2000 to 2020 were reviewed. The main objectives of this review were to: (1) obtain a clear understanding of the occurrence and environmental behavior of triadimefon in aquatic environments; (2) identify triadimefon exhibiting toxic effects and potencies and then to combine exposure and responses to assess current risks in aquatic environments; (3) identify knowledge gaps and propose future research needs, to provide a reference for management of triadimefon in aquatic environments, particularly in China.

\section{Environmental behavior of triadimefon in aquatic environments}

Environmental behavior of pesticides including migration and transformation in various environmental media determines the ultimate exposure to aquatic organisms. The environmental behavior of pesticides included the process of chemical behavior (release of residues, degradation, and biotransformation), physical behaviors (leaching and runoff, soil adsorption, volatile, and 
diffusion migration), and biological effects (bioaccumulation and adverse effects on organisms). Occurrences and sources in surface water, biota sorption, abiotic transformation and degradation, bioaccumulation, metabolism, elimination, and potential for biomagnification of triadimefon were summarized.

\section{Occurrence and source of triadimefon in surface water}

Due to the widespread use and rates of application and mobility, triadimefon is ubiquitous in the environment, and relatively higher concentrations of triadimefon have been detected in soil and food [25]. However, information on concentrations of triadimefon in surface water is relatively less. One day after treatment, residues of triadimefon and its metabolites from a turfgrass facility ranging from 46 to $922 \mu \mathrm{g} / \mathrm{L}$ [26]. A study of pesticide monitoring in Amvrakia Lake (Western Greece) found that after changing the use type of agricultural land, the maximum concentration of triadimefon was $0.0371 \mu \mathrm{g} / \mathrm{L}$ [27]. A 3-year monitoring survey (March 2005-February 2008) in Acheloos River (Western Greece) found that the maximum concentration of triadimefon was $0.1923 \mu \mathrm{g} / \mathrm{L}$ [28]. Some studies also involved measuring triadimefon in the surface water of China (Additional file 1: Table S1). The pollution status of nine triazole pesticides were investigated at 16 points along the Jiulongjiang River. Results indicated that during the wet season, concentrations of triadimefon ranged from 0.1733 to $0.047 \mu \mathrm{g} / \mathrm{L}$, with a rate of detection of $43.8 \%$, but during the dry season, triadimefon was never detected at any location [7]. Concentrations of triadimefon in ditches around rice fields ranged from 0.4 to $12 \mu \mathrm{g} / \mathrm{L}$, and the detection rate was $33.3-100 \%$ [8], which indicated that application of triadimefon resulted in relatively higher concentrations of triadimefon in the surrounding aquatic environments. When samplings of drinking water sources were conducted at Red Maple Lake, Baihua Lake and the Aha Reservoir, in Guiyang province during the dry season from 2014 to 2015, concentrations of triadimefon were $1.1-4.1 \mu \mathrm{g} / \mathrm{L}$, and the detection rate was 33.3\% [5]. During the same period, 11 sampling sites were established by adding one site in the Songbaishan Reservoir. The rate of detection of triadimefon was $33.6 \%$, and concentrations ranged from 0.185 to $5.220 \mu \mathrm{g} / \mathrm{L}$ [3]. The maximum concentration of triadimefon in the Tai Lake Basin was $0.00727 \mu \mathrm{g} / \mathrm{L}$, but the detection rate was $100 \%$, while the maximum detected concentration in Baiyangdian Lake was $0.13 \mu \mathrm{g} / \mathrm{L}[29,30]$. Besides, triadimefon was also detected in three rivers, Bai, Chao and Chaobai, and a reservoir, Miyun, in Beijing, and some other waters including Poyang Lake, Ganjiang River, and Xiushui River of Jiangxi Province. In those surveys, the maximum concentration was $0.054 \mu \mathrm{g} / \mathrm{L}$ (Additional file 1: Table S2).
Concentrations of triadimefon in rivers of Beijing, Shanghai, and Jiangsu provinces were relatively low, but higher in the surrounding watersheds of agricultural land, to which triadimefon was applied. The concentrations of triadimefon in the source of drinking water of Guiyang reached several micrograms per liter [5]. The concentrations in water in locations outside of China tended to be less because the use of triadimefon in those areas is relatively less, but triadimefon has been detected in most surface waters, although at low concentration. The mean rates of removal of triadimefon by municipal sewage treatment plants, after secondary and tertiary treatments, were $65 \%$ and $93 \%$, respectively [31]. Therefore, wastewater treatment plant discharges might not be primary sources of triadimefon to aquatic environments.

\section{Degradation and metabolism}

Transformation and degradation of triadimefon in the environment and the metabolic process in organisms are determinants of whether triadimefon will persist in the environment and whether it poses a threat to aquatic environments and organisms. Triadimefon is composed of a chiral center and two enantiomers R-enantiomer (R-triadimefon, R-TDF) and S-enantiomer (S-triadimefon, TDF), respectively [32]. Triadimenol, which is a more potent fungicide than triadimefon, is the main product of degradation or metabolism of triadimefon. In the transformation process, the carbonyl group linked to the chiral center is converted to a hydroxyl group, giving rise to a new chiral center. Thus, two chiral centers and four stereoisomers can result $[33,34]$. They were $1 R$, 2R- (-)-triadimenol (RR-TDN), 1R, 2S- (-)-triadimenol (RS-TDN), 1S, 2R- (+)-triadimenol (SR-TDN), and 1S, 2S- (+)-triadimenol (SS-TDN) [35, 36] (Fig. 1).

\section{Abiotic and biotic transformation and degradation}

There are several pathways and mechanisms of transformation and degradation of triadimefon and it has different durations of persistence in various environmental matrices (Additional file 1: Table S3). Hydrolysis of triadimefon is the primary abiotic mechanism of transformation [37-39]. Triadimefon was stable under acidic conditions and not easy to hydrolyze. However, at higher $\mathrm{pH}$ or higher temperatures, hydrolysis was accelerated [39]. In simulated aquatic environments, the half-life of triadimefon was 5.3 days and 1.15 days at $\mathrm{pH} 7.18$ and $\mathrm{pH}$ 9.25, respectively. Those results were similar to results in a buffer solution [37]. In an alkaline aqueous environment, hydrolysis might be one the primary mechanism by which triadimefon disappears, but in an acidic aqueous environment, it is difficult to remove triadimefon by hydrolysis. 


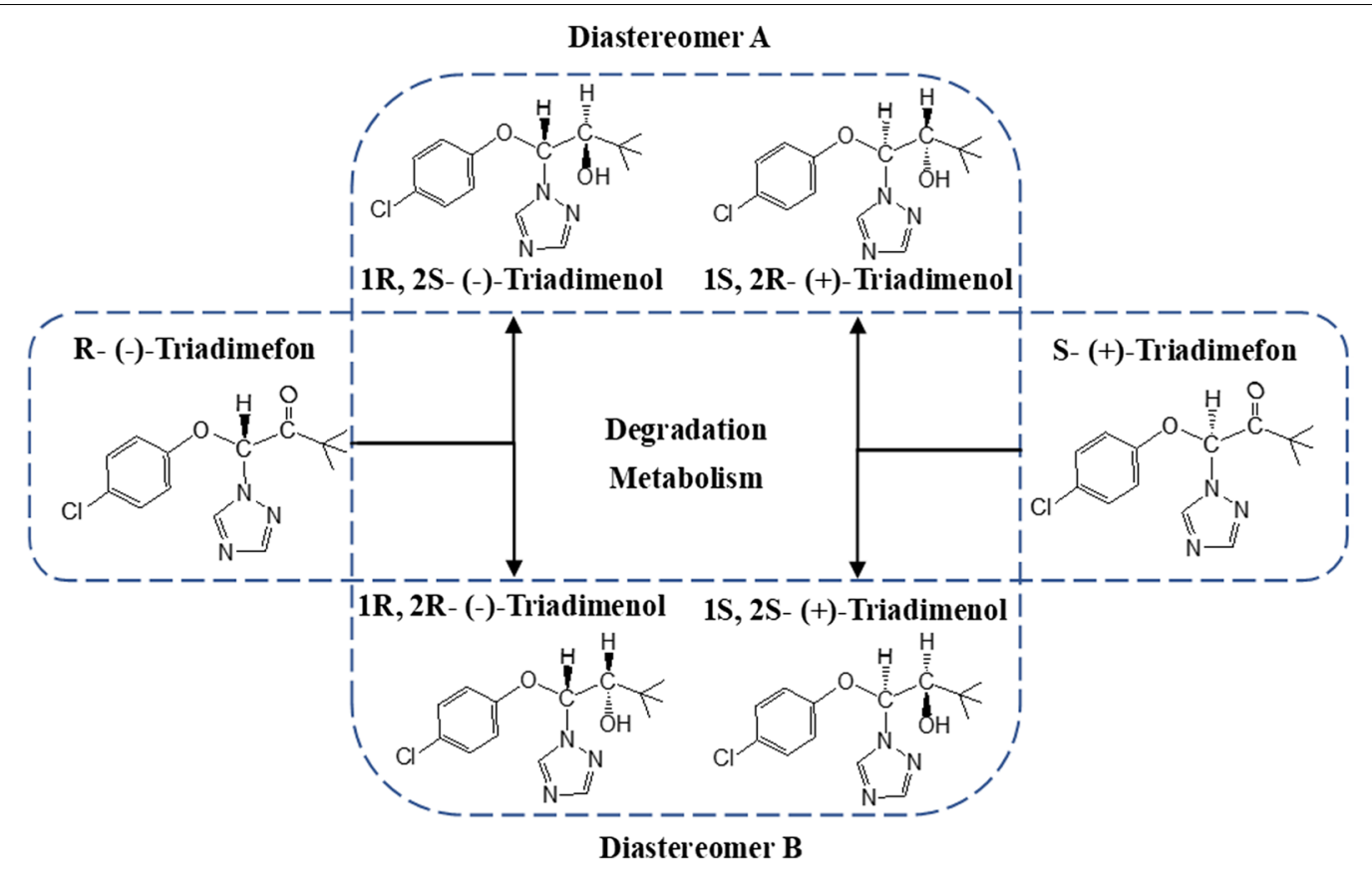

Fig. 1 Degradation and metabolism of triadimefon. The degradation and metabolism products of isomer R-TDF are RR-TDN and RS-TDN, and the degradation and metabolism products of isomer S-TDF are SS-TDN and SR-TDN

There is slightly more information about photolysis of triadimefon than there is on hydrolysis. Under natural sunlight conditions, the half-life of triadimefon in ultrapure water was 11.7 days. Half-lives of sterilized river water and seawater were 16.5 days and 22.3 days, respectively [7]. It was significantly delayed in river water, compared to ultrapure water. Solvent and irradiation wavelength were the major factors affecting photodegradation of triadimefon [7]. Triadimenol, the main metabolite of triadimefon, was more stable to photolysis than triadimefon [40]. With electron-acceptor sensitizers and longer durations of irradiation, significant degradation of triadimenol can occur [41]. Homolytic cleavage of the $\mathrm{C}-\mathrm{N}$ and $\mathrm{C}-\mathrm{O}$ were major mechanisms to photolytic attack of triadimefon during photo-degradation in methanol and cyclohexane [42, 43]. 4-Chlorophenol and 1,2,4-triazole were two major products of photodegradation of triadimefon or triadimenol [42]. However, studies of photolysis of triadimefon have focused primarily on mechanisms and factors influencing degradation. Information on photolysis in natural waters which might attenuate light or contain photosensitizing compounds such as humic acid and fulvic acids are lacking. Quantum yields of photo-degradation of triadimefon indicated that rates of photo-chemical reactions observed in the presence of organic solvents could not be applied to natural aquatic systems [40]. Therefore, more studies based on natural aquatic systems are needed to explore the photo-chemical behavior and persistence of triadimefon under more realistic natural conditions.

In dry soils, the primary degradation product of triadimefon is triadimenol, due to reduction of the carbonyl group to an alcohol, but in flooded soils, triadimefon is degraded to the diol derivative [1-(1H-1,2,4-triazol-1-yl)3,3-dimethylbutan-2-one-1,4-diol] [34, 44]. Thus, the rates of transformation and products formed are influenced by soil moisture content. In addition, degradation of triadimefon is also affected by organic carbon content and temperature [44]. The biotransformation rate of triadimefon in the soil can be affected by $\mathrm{pH}$, such as the rate of biotransformation in soil with a $\mathrm{pH}$ of 6.3 was approximately twice that of soil with a $\mathrm{pH}$ of 4.8 [34]. By contrasting the result of sterilized soil and non-sterilized soil, the degradation of triadimefon in soil was mainly biologically mediated. The microorganisms Arthrobacter and Halomonas played important roles in converting R-TDF to S-TDF and S-TDF to R-TDF in neutral and alkaline soil, respectively [45]. Thus, triadimefon would not persist very long in soil, with observed half-lives of 8 days in sandy-loam and 13 days in clay soils [46], 5.2 days in facility soil [47] and finally 39.4 days in sterilized soil [45]. But, triadimenol, the degradation product of triadimefon, is much more persistent, with a half-life exceeding 240 days [33, 44, 48]. Concentrations of triadimenol in surface water can be several micrograms per liter. Therefore, the persistence of triadimefon and 
its degradation production triadimenol in the environment cannot be ignored. Whether triadimefon can be transported long distances to polar regions has not been determined.

Degradation of triadimefon in soil exhibits significant stereoselectivity. Stereoselectivity refers to that chiral drugs entering the environmental system can change the enantiomer ratio due to various chiral factors. This process of changing the enantiomer ratio is referred to as the stereoselective behavior of chiral molecules. In soil, Biotic transformation product of triadimefon is triadimenol with different relative abundances of the four stereoisomers [32, 47]. In addition, under different soil or physical conditions, the stereo-isomer components of triadimenol formed by conversion of triadimefon can result in different ratios. [33]. Triadimefon is a chiral pesticide, and during its degradation process, abiotic racemization would occur [33, 43], which would affect the isomer composition and proportions of products. Different stereoisomers might have different biological properties. For example, acute toxic potency of triadimenol diastereomer $\mathrm{A}$ to rats (oral $\mathrm{LD}_{50}$ ) is ten times greater than that of diastereomer B [49]. Therefore, it is essential to take into account stereoselectivity and configurational stability when assessing risks of triadimefon and triadimenol to aquatic organisms.

\section{Metabolism and elimination}

Triadimefon has one chiral center and two enantiomers, R-TDF and S-TDF. The metabolite of triadimefon in organisms, which is triadimenol, was found in several studies [36, 50-52]). During metabolic transformation, the carbonyl group attached to the chiral center is reduced to a hydroxyl group, which results in a new chiral center. As a result, triadimenol possesses four enantiomers, including SS-TDN, SR-TDN, RR-TDN, and RS-TDN. Unfortunately, triadimenol also exhibits toxic potency to organisms. A study of the stereoselectivity of triadimenol metabolism indicated that triadimenol can be enriched in lizards and cause reproductive toxicity, hepatotoxicity, and oxidative stress $[35,52]$. Also, triadimenol can cause neurological toxicity through interference with normal functioning of the acetylcholinesterase (AchE) [35]. Triadimenol exhibited greater inhibition of Scenedesmus obliquus than did triadimefon [36].

Absorption, distribution, metabolism, and elimination of triadimefon and triadimenol enantiomers in tissues, including liver, brain, fat, kidney, and blood plasma, of the Eremias argus were studied after orally giving lizards R-TDF or S-TDF [50]. Traits of rapid distribution and slower elimination of triadimefon enantiomers in the tissue were observed. Biotransformation, degradation, and dynamic metabolic process varied among tissues.
The main metabolites of each triadimefon enantiomer were also different. For instance, the main metabolite of R-TDF was RR-TDN, while that of S-TDF was SR-TDN. The metabolic rate of these metabolite isomers was also different. Selective metabolism and toxic effect of triadimenol have been also observed [35]. The metabolic rates of RS-TDN and RR-TDN were more rapid than that of SR-TDN and SS-TDN, respectively. S-TDF was absorbed faster than R-TDF, and R-TDF was easily metabolized to TDN in lizards [51]. However, in in vitro tests in rainbow trout (Oncorhynchus mykiss), S-TDF was more easily transformed to triadimenol than R-TDF [53], which illustrated the species differences in stereoselective metabolism of triadimefon. Therefore, different species and different tissues and even different media can exhibit different compositions and distributions of metabolite stereoisomers [50-52, 54, 55]. The biological activity of triadimenol probably depends on the relative abundances of its particular stereoisomers. Each isomer is a separate entity, and its behavior in the environment and toxicity to organisms might be different. For example, enantiomers of triadimenol had different toxic effects on fungi and rats [56]. Significant differences in metabolism and toxic effects between enantiomers were found in selective metabolism of triadimefon by vegetables [35]. Significant differences among isomers also were observed during acute studies of toxicity to the water flea (Daphnia magna) [55]. The toxic potencies of both triadimefon and triadimenol are complicated. The liver is the main place for metabolism of pollutants in the body, so research on the metabolic kinetics of pollutants was carried out in vitro, by use of liver microsomes. In the early years, some researchers also carried out in vitro liver microsome experiments on triadimefon [57] to study the gender and species differences of triadimefon metabolism in rodents in vitro [58] and to explore the metabolic mechanisms by which triadimefon differed from other conazole fungicides, such as steroidogenesis and carbohydrate metabolism [59].

In summary, although triadimefon does not persist in the body for a long time, its metabolite, triadimenol, remains for a longer time and may be more toxic. Moreover, its metabolism is stereoselective, which leads to the uncertainty of its metabolite isomer composition and further leads to the complexity of its toxicity. Therefore, these characteristics should be fully taken into account in the risk assessment of triadimefon.

\section{Bioaccumulation and biomagnification}

The factors bioconcentration (BCF), bioaccumulation (BAF), and biomagnification (BMF) are regarded as the main coefficient to describe the potential for compounds to be accumulated into biota. BCF refers to the ratio of 
the concentration of a pollutant in an aquatic organism to the concentration of this substance in water. Unlike BCF, BAF represents the net bioaccumulation of pollutants absorbed by organisms from all environmental sources. BMF represents the ability of pollutants to transfer along with trophic levels. BCF can be estimated by use of the octanol-water partitioning coefficient (log $\left.K_{\text {OW }}\right)$ and metabolism. Triadimefon $\left(\log K_{\text {OW }} 3.1\right)$ [53] is characterized as having moderate lipophilicity and longterm stability [60], almost $95 \%$ of triadimefon remained after 28 weeks in water at a $\mathrm{pH}$ of $3.0,6.0$, or 9.0 [32]. According to the Reregistration Eligibility Decision of US EPA, triadimefon can bioaccumulate into tissues of fishes [4]. The elimination half-life has been calculated to be 1.1 days via dietary exposure of juvenile rainbow trout [53]. In addition, there is some information on bioaccumulation of triadimefon in the black-spotted frog tadpoles, Tubifex tubifex, Bellamya aeruginosa, and Scenedesmus obliquus. Bioaccumulation of triadimefon by $S$. obliquus reached its maximum on the 7 th day. BCFs of R-TDF and S-TDF were $67.32 \mathrm{~L} / \mathrm{kg}$ and 67.09 $\mathrm{L} / \mathrm{kg}$, respectively [36]. This result indicated that bioaccumulation of triadimefon by $S$. obliquus was not enantioselective. However, bioaccumulation in the frog was stereoselective, and S-TDF was absorbed preferentially. This result was consistent with bioaccumulation of triadimefon by T. tubifex [34]. After exposure to triadimefon, the maximum BCF of B. aeruginosa was 19.4 [61]. Compared with BCF, the bioaccumulation ability of triadimefon in $S$. obliquus was significantly stronger than the other three. Triadimefon has little enrichment potential. However, the metabolite, triadimenol, might have stronger enrichment capacity. The isomers SS-TDN with BCF of 1.44 greater than that of S-TDF [52]. Triadimenol could also bioaccumulate in the lizard, especially RRTDN (produced by R-TDF) [35]. However, there were species differences in this condition, and the opposite result appeared in algae. The bioaccumulation capacity for triadimenol was significantly less than that of triadimefon [36].

A study related to the biomagnification of triadimefon demonstrated stereoselective behavior of triadimefon and triadimenol in a simple food chain of algae-tadpole. The concentration of triadimefon in algae-eating tadpoles was less than that of algae. The biomagnification factor of the enantiomer for the algae-tadpole system did not result in biomagnification, but rather diminution or a decrease in the concentration with trophic level [36]. But the tadpoles that ate algae containing triadimefon were still exposed to the triadimefon enantiomer, which caused chronic toxicity including sub-lethal effects and death. Because of the long-term low doses of triadimefon, more research about bioaccumulation and biomagnification are needed to better understand the behavior of triadimefon in aquatic environments and aquatic organisms.

\section{Effects and mechanisms of toxicity of triadimefon to aquatic organisms}

According to the harmonized classification and labeling (CLP00) approved by the European Union, triadimefon was toxic to aquatic organisms with long-lasting effects. Many relevant studies on the effects of triadimefon have been conducted. Since adverse effects of triadimefon on human health were of most concern, most of the studies have focused on animal models, including mammals, such as rats and mice. The toxic effects of triadimefon on aquatic organisms have focused mainly on amphibians, such as the African clawed frog (Xenopus laevis) and black-spotted frog (Rana nigromaculata), fish such as Zebrafish (Danio rerio), rare minnow (Gobiocypris rarus), rainbow trout (Oncorhynchus mykiss), and Japanese medaka (Oryzias latipes), as well as zooplankton water flea (D. magna), and algae. A review of the last 20 years of research found that triadimefon can affect species by causing multiple toxic effects on the thyroid, reproductive system, liver, and nervous system as well as carcinogenicity and teratogenicity $[12,16,20,62]$. Furthermore, synergistic effects with other pesticides were also observed $[13,63,64]$. In this study, the effects and mechanisms of action and toxic potencies of triadimefon have been summarized.

\section{Developmental and reproductive toxicity}

The developmental and reproductive toxicity of triadimefon have been reported and demonstrated in various organisms and their various life stages, including adult African clawed frog, black-spotted frog tadpoles, zebrafish, rare minnow larvae, and water flea. Triadimefon can adversely affect sexual development and reproductive success through a variety of endocrine processes. Exposure to triadimefon can impair reproductive function in various animals, associated with an imbalance of sex hormones [65] and dysfunction of receptor signaling pathways [16].

Studies of the effects of triadimefon and its transformation product on adult African clawed frog demonstrated that triadimefon and its metabolite (triadimenol) potentially affected African clawed frog through endocrine-disrupting [14] and inhibiting growth of frogs [15]. Similarly, triadimefon can influence the development of black-spotted frog tadpoles [66]. Disruption of hormones involved in metamorphosis contributed to toxicity to tadpoles. The toxic potency of triadimefon to tadpoles was greater than that of the metabolite, triadimenol, at both higher and lower concentrations, which should be taken into 
account when assessing the hazard or risks of triadimefon. There were sex-specific differences in the expressions of genes related to thyroid hormone and reproduction. Thus, triadimefon might contribute to the global decline of amphibians, but as of now, there is no direct evidence of this supposition. But, triadimefon might contribute to population-level effects in wild amphibians, so to ensure better protection of natural communities of amphibians and maintain healthy ecosystem function, some fieldlevel studies may be warranted. A similar conclusion on the developmental toxicity of triadimefon on African clawed frog tadpoles was also suggested [12]. Triadimefon altered the expression of genes in the HPT axis, down-regulation of thyroglobulin, and up-regulation of genes related to thyroid hormone metabolism (ugt1ab) and disrupted synthesis, regulation, and action of thyroid hormones in African clawed frog tadpoles. Thus, disruption of thyroid hormone function in African clawed frog tadpoles exposed to triadimefon consequently delayed thyroid hormone-dependent metamorphic development $[12,66,67]$. That result was consistent with results of previous studies of the endocrine-disrupting effects of triadimefon on the zebrafish $[67,68]$. Incomplete metamorphosis can cause a complete loss of one generation of pond-breeding frogs, ultimately resulting in a decline of populations [66].

In fish, the toxic effects of triadimefon on development and reproduction are significant. Triadimefon has negative effects on the development of each life stage (embryo [22], larvae [11], adult [22]) of fish such as zebrafish and rare minnow. Incubation, which is the process of breaking out of the chorion from the embryo to the individual, is the transition point of the larva and is sensitive to the effects of chemicals. This sensitive developmental stage is often used to assess the effects of different factors on early developmental and reproductive capacity of aquatic animals. Exposure to triadimefon significantly reduced the hatching success of zebrafish embryos, with exposure to $35.6 \mathrm{mg} / \mathrm{L}$ [69]. This effect might due to inhibition of secretion of hatching gland cells (HGC) [16]. These results indicated that triadimefon can impair critical events during early life stages of fishes through a specific pathway. Also, triadimefon disrupted endocrine functions including causing anti-estrogenic effects and oxidative stress $[11,70]$ in larvae of rare minnow (Gobiocypris rarus). Triadimefon caused anti-estrogenic effects by decreasing vitellogenin (VTG) and CYP19a mRNA level. Because CYP19a can catalyze conversion from testosterone to estradiol $\left(E_{2}\right)$, the synthesis of $E_{2}$ was restrained due to this effect $[11,70,71]$. Triadimefon also caused reproductive toxicity to fish and even humans via key receptor signaling pathways. Exposure of triadimefon caused reproductive toxicity to zebrafish, which was expressed in the form of disorder of cell maturation and decreased spawning behavior and production of eggs [23]. These results were consistent with results of a previous study where exposure of $0.25 \mu \mathrm{g} / \mathrm{mL}$ triadimefon reduced reproductive success, based on the numbers of eggs produced and spawning behavior [24]. 21-day oral exposure of triadimefon disrupted endocrine homeostasis in Eremias argus via altering the concentrations of sex steroid hormones testosterone and $\mathrm{E}_{2}$, and inhibiting the activities of the cytochrome P450 enzyme (CYP). Relative expressions of steroidogenic-related genes (Era and Ar, cyp17 and cyp19, and $h s d 17 \beta$ ) were also affected after 21 days of exposure to triadimefon, leading to abnormal reproductive behavior [72]. These results argue that triadimefon is a potential endocrine disruptive chemical, as defined by the European Union and World Wide Fund for Nature in 2006. In invertebrates, triadimefon can delay molting and development and cause developmental abnormalities among offspring, eventually reducing the reproductive fitness of the cladoceran, D. magna [17].

\section{Teratogenic and carcinogenic effect}

Studies on the teratogenic effects of triadimefon have focused on malformations of development, primarily of branchial arches in amphibians and zebrafish or mammalian embryos. After being exposed to triadimefon during the neurula stage, teratogenic effects were observed in cartilages and muscles of the first and second branchial arches in X. laevis [73]. Exposure to $4 \mu \mathrm{g} /$ $\mathrm{mL}$ triadimefon caused teratogenic effects during the development of zebrafish embryos [22]. In mammals, relatively small doses of triadimefon or triadimenol can affect branchial development in rat embryos and exhibit teratogenic effects after being exposed during neurulation [21]. Exposure of mouse embryos to triadimefon during early embryo development caused craniofacial malformations like reducing and fusing the first and second branchial arches [74-76], axial deformities, and maxillary ectopic cartilage [76]. When early development embryos of Phallusia mammillata were exposed to triadimefon, malformations were observed in a dose-dependent manner [77]. Both triadimefon and triadimenol have been classified as "possible human carcinogens" [4]. Triadimefon can induce tumorigenesis in rodents, including thyroid tumors and liver tumors [78]. In fish, triadimefon enhanced CYP3A and CYP1A activities, which were associated with tumorigenesis in 
adult medaka [79], but there are fewer studies of how triadimefon and/or its metabolite(s) cause these effects.

\section{Neurotoxicity, hepatotoxicity, and cardiovascular toxicity}

Some studies have indicated that triadimefon and triadimenol can cause neurotoxicity, hepatotoxicity, and cardiovascular toxicity in mammals and fish. These findings suggest potential effects might occur not only in aquatic ecosystems, but in humans as well. Triadimefon and triadimenol cause effects on mammalian central nervous systems [80] of rats, mice, and rabbits [4, 59, 81]. Exposure of mammals to triadimefon resulted in increases in concentrations of dopamine at synapses. The mechanism of action for this effect was similar to that caused by cocaine, which was bind to the dopamine transporter, thus inhibiting the uptake of monoamine [82]. Neurotoxic syndrome in rats, is characterized by increasing motor activity [82, 83], can be related to aggressiveness when adult zebrafish were exposed to $5 \mathrm{mg} / \mathrm{L}$ triadimefon. This result suggests that triadimefon could also cause neurotoxicity in aquatic ecosystems [18]. The least concentration altered neither locomotor activity nor concentrations of dopamine, but caused changes in expressions of two genes, tyrosine hydroxylase 1 (th1) and dopamine transporter (dat). Triadimefon also reduced extracellular serotonin and had an anxiolytic-like effect, accompanied by less production of cortisol. Higher concentrations of triadimefon resulted in a dose-dependent reduction in locomotion, which was reversed or enhanced by $\mathrm{SCH}-$ 23390 (D1) or haloperidol (D2) dopamine receptor antagonists, respectively [18].

Liver tissue is rich in metabolic detoxification enzymes, such as CYP [84], and is important for detoxification, but subject to cause damage of tissues due to oxidative stress. Exposure to triadimefon might inhibit CYP enzyme activity and can damage the liver, with increased duration of exposure. During a 21-day oral exposure of triadimefon and its enantiomers to Eremias argus, triadimefon caused hepatocellular damage and affected normal physiological function of the liver. The two enantiomers exhibited different degrees of damage [72]. Damage to liver cells may in turn lead to reproductive and developmental effects. When toxic effects of triadimefon and triadimenol on human hepatocytes were explored in vitro, the effects were dose dependent. Exposure to lesser concentrations $(<20.998 \mu \mathrm{g} / \mathrm{mL})$ significantly $(P<0.05)$ promoted cell proliferation, while at high concentrations $(40-200 \mu \mathrm{g} / \mathrm{mL})$ significantly inhibited cell proliferation $(P<0.05)$. All cells died at concentrations of triadimefon higher than $190.203 \mu \mathrm{g} / \mathrm{mL}$ [85]. In rodents, triadimefon also caused hepatocyte hypertrophy in a dose-dependent manner [19]. When studying the toxic effects on liver, it is necessary to consider the toxicity of chiral enantiomers and metabolites of triadimefon as well as their combined toxicity.

Triadimefon can adversely affect the cardiovascular system, but less information is available. Triadimefon negatively affected the morphology and functions of the zebrafish cardiovascular system by down-regulating genes related to the calcium signaling pathway and cardiac muscle contraction [20]. It was specifically shown in pericardial edema, circulation abnormalities, serious venous thrombosis, greater distance between the sinus venosus, bradycardia, and a significantly reduced of cardiac output. More attention should be paid to the harm of triadimefon to human health, especially the occupational population, including farmers, retailers, and pharmaceutical workers. But the risk of triadimefon to the cardiovascular system of humans has been rarely studied, which should be considered in future studies and assessments of effects of triadimefon on health of humans.

\section{Toxic mechanisms and pathways}

Toxic mechanisms and pathways of triadimefon on aquatic organisms, including fish, amphibians, and invertebrates, are developed and summarized in this section (Figs. 2, 3, 4).

Toxic mechanisms and pathways of triadimefon on fishes and amphibians include embryo hatching, fecundity, the ratio of male to female, neurotoxicity, and cardiovascular toxicity (Figs. 2 and 3). Metamorphic development was a predominant effect of triadimefon on amphibians. Triadimefon can interfere with thyroid hormones via altering the expression of genes related to the HPT axis, eventually affecting the rates of hatching of embryos and reducing reproductive capacity in fish [16]. This pathway also applies to amphibians [12]. Triadimefon also regulated expressions of mRNA coding for VTG, the precursor of the lipoproteins and phosphoproteins that make up most of the protein content of egg yolk, and CPY19a, thereby inhibiting the aromatase activity and concentrations of VTG to cause an anti-estrogenic effect and reduce fecundity [86]. Accelerating conversion of androstenedione to testosterone and forestalling transformation from testosterone to $E_{2}$ were other pathways that could reduce fecundity. The signaling pathways of reproductive toxicity were related to the decrease in the secretory function of the HGCs, inhibition of sperm and egg production and maturation [55], reduction of sperm density and motility, and immature gonad development exposed of fish to triadimefon. Dopamine-related neurotoxicity might be associated with secretion of chitinolytic enzyme, which would link neurotoxicity to reproductive toxicity. Oxidative stress and peroxidation of the membrane lipids were detected whether in fish [11,23] or amphibians [14]. Besides, changes in the expressions of 


\section{: Gene-level Response \\ : Protein-level Response \\ : Individual-level Response}

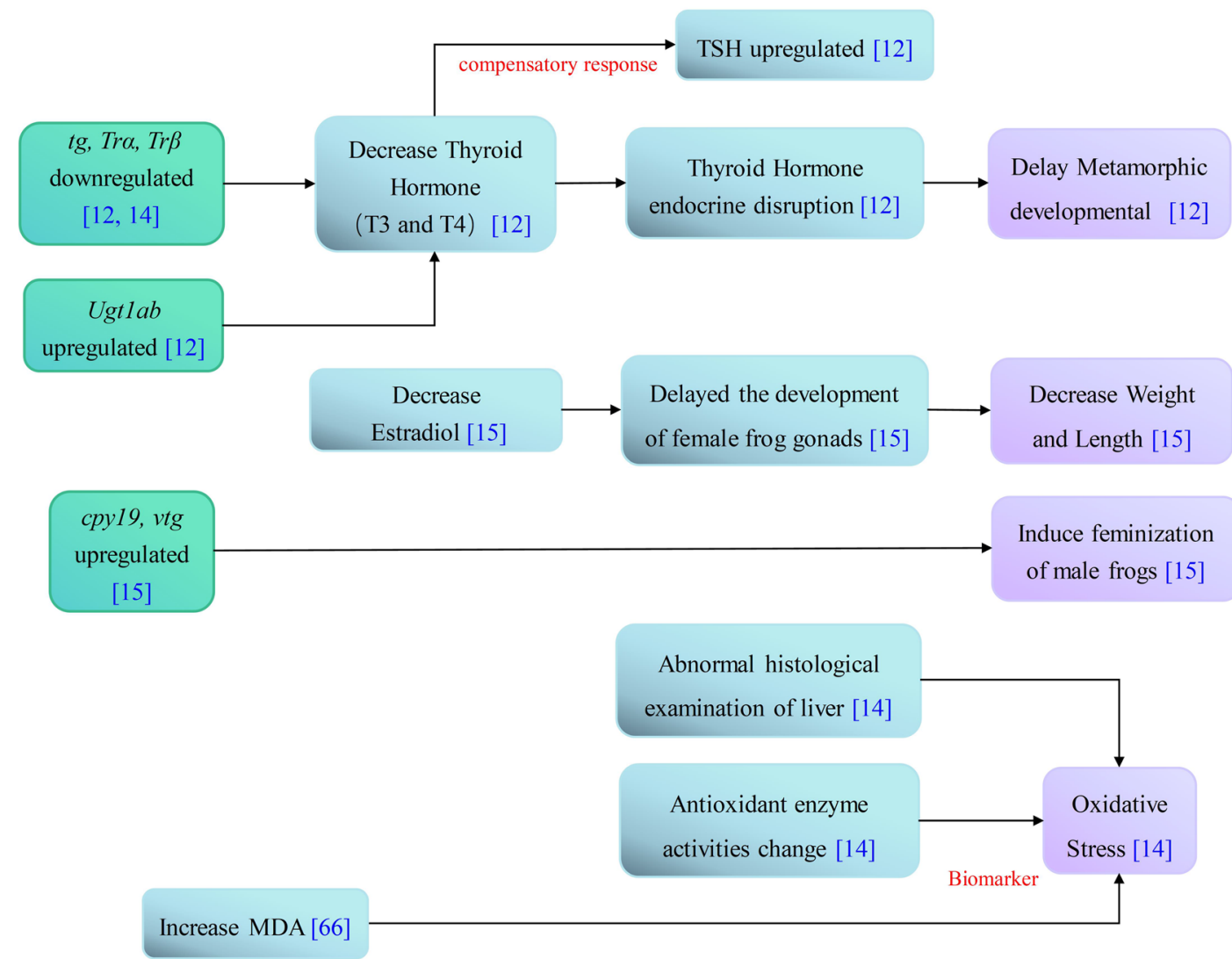

Fig. 2 Schematic diagram of the toxic mechanisms and pathway on exposure of aquatic amphibians to triadimefon. The green portion of the diagram represents the effects at the gene level, while the violet portion of the diagram represents the adverse outcome expressed in the individual. Finally, the cyan violet portion of the diagram represents response in protein or hormone where links to gene-level response could be linked to individual-level response

genes related to ATPase, including atp2a1l, atp $1 b 2 b$ and $a t p 1 a 3 b$, calcium channel-related genes, cacnalab and cacnalda, and cardiac troponin $C$ (tnncla) might also be molecular-initiating events involved in the mechanism of triadimefon in cardiovascular toxicity [20].

The toxic mechanisms and pathways of triadimefon on aquatic invertebrates (Fig. 4) are relatively simple, since currently information on the mechanisms of the toxic effects of triadimefon in invertebrates are relatively limited. Triadimefon reduces the synthesis of ecdysis hormone in crustaceans by inhibiting the activity of $\mathrm{P} 450$ enzymes [58, 64]. The results of these studies demonstrated that exposure to triadimefon $(0.05 \mathrm{mg} / \mathrm{L}) \mathrm{sig}$ nificantly reduced the numbers of molts and prolonged the durations of inter-molt period times of $D$. magna, thus affecting populations [87]. Malformations of the eyes of exposed D. magna offspring were also observed.
Therefore, it can be speculated that triadimefon can adversely affect the ecological fitness of invertebrates, which could result in population-level decreases in fitness.

As a fungicide, triadimefon is seldom applied alone, but often together with other agricultural chemicals including herbicides and insecticides in aquatic ecosystems, and thus its combined toxicity cannot be ignored. Perfluorooctanoic acid, which can be present in some formulations, significantly increased the toxic potency of triadimefon [63]. The 96-h exposure of rare minnow to a mixture of fenvalerate $(0.288 \mathrm{mg} / \mathrm{L})$ and triadimefon $(6.44 \mathrm{mg} / \mathrm{L})$ illustrated that the two chemicals can interact to cause acute toxicity, endocrine disruption, and oxidative stress during rare minnow embryo development at lesser doses [13]. Co-exposure of zebrafish to triadimefon and butachlor [62] or fludioxonil [88] also 


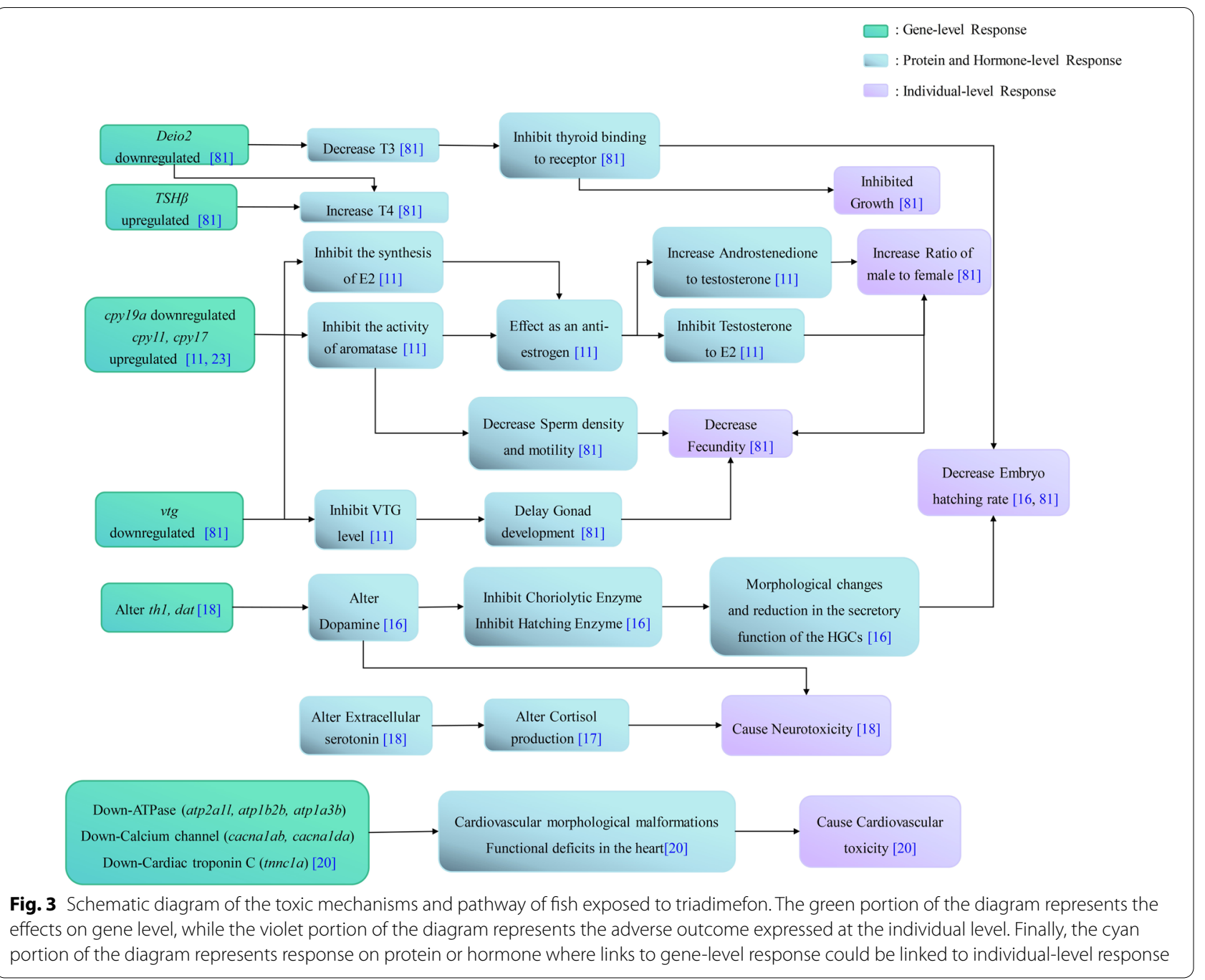

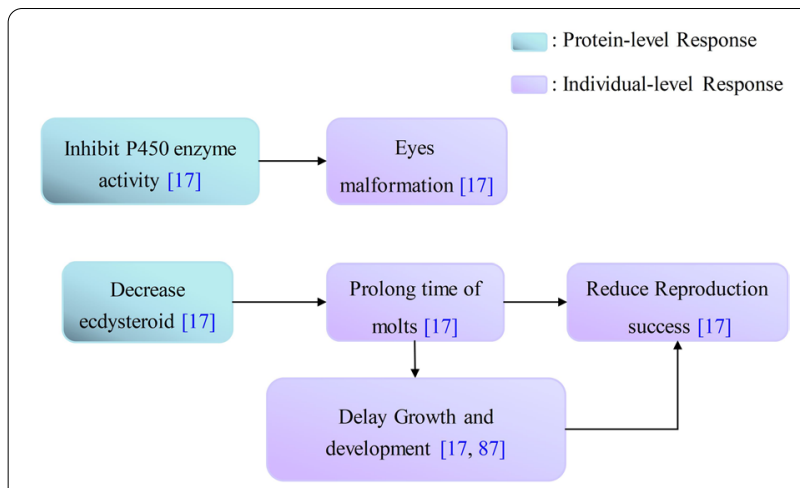

Fig. 4 Schematic diagram of toxic mechanisms and pathway for exposure of aquatic invertebrates to triadimefon, which is based on currently available results. The cyan portion of the diagram represents response in protein or hormone, while the violet portion of the diagram represents the adverse outcome expressed at the individual level exhibited a synergistic effect on the embryonic development and thyroid endocrine disruption. Combined toxic effects of triadimefon and other pollutants in the ecological risk assessment of triadimefon in aquatic ecosystems deserves more attention.

\section{Assessment of risk posed by triadimefon to aquatic organisms \\ Predicted no-effect concentration of triadimefon based on various measurement end points}

Screening for potential endocrine-disrupting effects and in particular effects on estrogen suggested that triadimefon resulted in endocrine-disrupting effects, and particularly estrogenic effects [9]. Although the concentration of triadimefon in surface waters is generally not very high, triadimefon can persist in aquatic environments for relatively long durations and can cause reproductive damage to aquatic organisms even at small concentrations. Various species or different life stages of the same 
species might exhibit different responses and mechanisms, and there are gender-specific effects. As a result of the existence of stereoselectivity, toxic effects interpretation of this chiral compound is further complicated. Also, triadimenol, a degradation product of triadimefon, can exhibit greater toxic potency than triadimefon. Triadimefon poses ecological risks to populations of aquatic animals that can result in dysfunction of ecosystem processes and minimize ecological services. US EPA established a screening value of $550 \mu \mathrm{g} / \mathrm{L}$ for protection of underground drinking water sources [4]. The OPP Aquatic Criterion also has defined an acute toxicity value of $2050 \mu \mathrm{g} / \mathrm{L}$ for fish, a chronic toxicity value of $170 \mu \mathrm{g} / \mathrm{L}$, and an acute toxicity value of $800 \mu \mathrm{g} / \mathrm{L}$ for invertebrates. However, it has been demonstrated that triadimefon affects the reproductive system of aquatic organisms at concentrations as small as $5 \mu \mathrm{g} / \mathrm{L}$. It is necessary to derive more scientific safety thresholds based on the endocrine disruptive potential effect, to reduce uncertainty and provide the basis for developing criteria for protection of aquatic ecosystems.

In this study, data for toxic potencies of triadimefon (Additional file 1: Table S4) were collected from the ECOTOX Knowledgebase (https://cfpub.epa.gov/ecotox/ search.cfm) developed by US EPA, following the principles of accuracy, relevance, and reliability [29]. A total of 28 toxicity values based on various end points for aquatic species met the criteria for data quality and were thus selected for further use. The numbers of toxicity values for triadimefon, based on end points including mortality, growth, reproduction and biochemical-cellular responses were $10,6,7$ and 5 , respectively. Toxicity data used to derive PNECs were selected using a hierarchical method. No observed effect concentrations (NOEC) or $\mathrm{EC}_{10}$ were preferred for growth and development, reproduction, and biochemical-cellular end points [89]. In the absence of an NOEC or $\mathrm{EC}_{10}$, the lowest observed effect concentration (LOEC) or the median effect concentration $\left(\mathrm{EC}_{50}\right)$ divided by an assessment factor (AF) of 2 or 10 was used $[89,90]$. Median lethal concentration $\left(\mathrm{LC}_{50}\right)$ was preferred for mortality. The assumption of a log-normal distribution was tested for each data set by use of the Anderson-Darling (A-D) test by ETX 2.0 software packages [91]. Species sensitivity distributions (SSDs) based on various assessment end points were fitted (Fig. 5) and the $\mathrm{HC}_{5}$ (hazardous concentration for $5 \%$ species affected) values were then derived by SigmaPlot 14 software packages. PNECs were calculated as the derived $\mathrm{HC}_{5}$ divided by a safety factor of 5 , which depended on the amount of supporting toxicity data [92]. The obtained PNECs based on assessment end points of mortality, growth and development, reproduction, and biochemical-cellular factors were 604.97, 3.95, 3.28 and $0.51 \mu \mathrm{g}$ triadimefon/L, respectively (Additional file 1 : Table S5). Based on SSDs curves, the most sensitive end point was biochemical-cellular. Sensitivity distributions were compared, by use of the two-sample KolmogorovSmirnov test, using the SPSS software version 26 (Additional file 1: Table S6). Differences in sensitivity among the end points of growth and development, reproduction, and biochemical-cellular factors were not statistically significant, while the sensitivity distribution of mortality

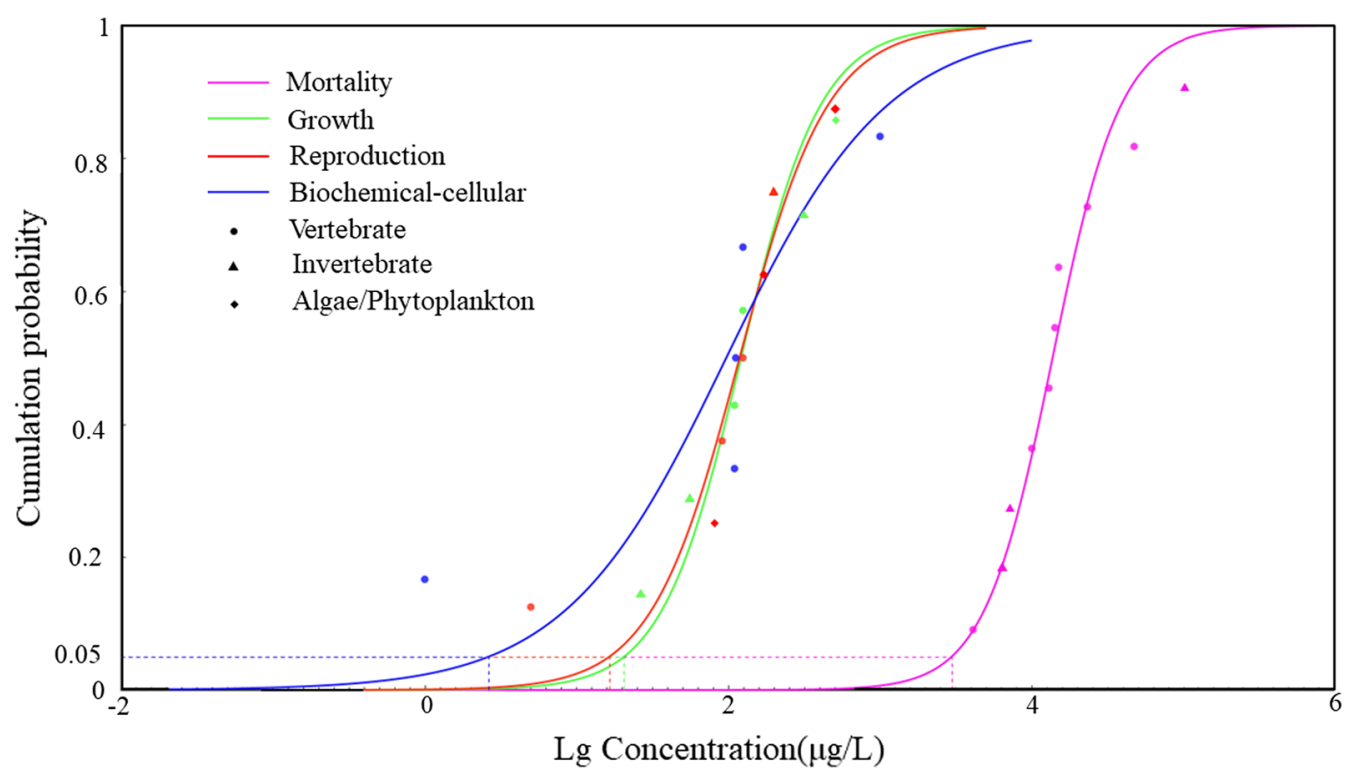

Fig. 5 Species sensitivity distributions (SSDs) for triadimefon (triadimefon) based on several end points for aquatic organisms 
was significantly different from those of the other three. A second screening was performed for toxicity data with growth and development, reproduction, and biochemical composition as end points to get the final PNEC $(1.30 \mu \mathrm{g} / \mathrm{L})$, which was chosen for use in calculating risk quotients. This value was slightly higher than the PNEC of $0.34 \mu \mathrm{g} / \mathrm{L}$ that was calculated by dividing the chronic toxicity value of two trophic levels of aquatic organisms by the safety factor 50 according to the method recommended in the technical guidelines for risk assessment of the European Union [28]. Alternatively, the PNEC based on the most sensitive test end point of nine aquatic organisms,was $3.66 \mu \mathrm{g} / \mathrm{L}$ [24], which was consistent with the PNECs based on growth/development $(3.95 \mu \mathrm{g} / \mathrm{L})$ and reproduction $(3.28 \mu \mathrm{g} / \mathrm{L})$ derived in this study.

\section{Ecological risk assessment of triadimefon}

To provide a more rigorous scientific basis and technical support for risk management options for triadimefon, two methods of ecological risk assessment were applied. These included both semi-probabilistic and fully probabilistic approaches.

\section{Risk quotient (RQ)}

Ecological risks caused by triadimefon in surface waters of China were assessed first by use of risk quotient (RQ), which were calculated as quotients of the maximum concentration of triadimefon in waters divided by PNEC (Eq. 1). The results are classified as insignificant if $\mathrm{RQ}<0.1$, low risk if $0.1 \leq \mathrm{RQ}<1$, moderate risk if $1 \leq \mathrm{RQ}<10$, and high risk if $\mathrm{RQ} \geq 10$ [29]. This approach was semi-probabilistic in that the PNEC was derived based on a probabilistic determination, but compared to a point estimate of exposures $\left(\mathrm{C}_{\mathrm{m}}\right)$

$$
\mathrm{RQ}=\frac{\mathrm{C}_{\mathrm{m}}}{\mathrm{PNEC}},
$$

where $C_{m}$ is the maximum concentration of triadimefon at each surface water; PNEC is the predicted no-effect concentration derived by the second screening chronic toxicity data, with AF of 5 .

RQ for Baihua Lake, Aha Reservoir, Red Maple Lake in Guizhou and the water around rice paddies in Zhejiang were $4.02,3.15,2.61$, and 9.23, respectively, all of which were defined as moderate risk (Fig. 6). The RQ for the Jiulongjiang River (0.13) and waters in Hainan (0.1) exceeded 0.1 , but were less than 1.0 , which were characterized as low risk. Other regions were defined as insignificant according to the results of RQ. If the PNEC of the most sensitive end points (biochemical-cellular) was chosen to calculate the RQ, Baiyangdian (0.25) in Hebei and Liangshui River in Beijing (0.11) would be also rated low risk. RQ can be influenced by the choice of PNEC based on different end points. In addition, environmental exposure data were collected from limited areas, and the actual risk of triadimefon in whole China or world is uncertain. More work is needed to acquire the detected concentrations of other representative areas. We would also further assess the risk of triadimefon caused to aquatic ecosystem by drawing the joint probability curves (JPCs).

\section{Joint probability curve}

Joint probability curves (JPCs) are a refined fully probabilistic method of assessing risks, which can protect the complex ecosystems better than RQ [93, 94]. The JPCs represent the probability of exposure as well as the probability of a species being affected, which can be based on both acute and chronic responses of various end points, ranging from lethality to growth or reproduction, which are the apical assessment end points most often employed in ecological risk assessments. JPCs are charted by the cumulative function of all biological toxicity data and the inverse cumulative function of pollutant exposure concentration, and the conclusion of risk assessment is expressed in the form of a continuous distribution curve while considering the uncertainty and variability of exposure concentration and toxicity data. The $\mathrm{X}$-axis represents the proportion of aquatic species predicted to be affected at a defined level of response. The Y-axis represents the probability of exceeding the concentration associated with a particular level of effect (proportion of species affected to a defined level of effect). This approach combines the duration and intensity of effects and expresses it as a probability of exposure and response $[95,96]$. The relationship indicates that while at higher concentrations the probability of response is greater, the probability of exceeding that concentration would be less. Each point along the JPCs curve represents the same product of the probability of exposure and associated probability of effect. Each point in the curve indicates the joint probability that a certain percentage of organisms will be affected in the target water body. The area under the curve is the region that would be expected to be affected up to that joint probability. The closer the joint probability density curve is to the $\mathrm{X}$-axis, the less likely organisms will be affected [94]. By this approach, ecological risks are characterized by regions of combined exposure and response: de-minimised risk (I), low risk (II), intermediate risk (III) and high risk (IV) [29, 97]. The JPCs of triadimefon based on different test end points (mortality, growth, reproduction, biochemical-cellular and the second screening of the 3 chronic end points) in China was drawn (Fig. 7). It demonstrates that risks of toxic effect of triadimefon to aquatic organisms based on end points of growth/development, reproduction, 


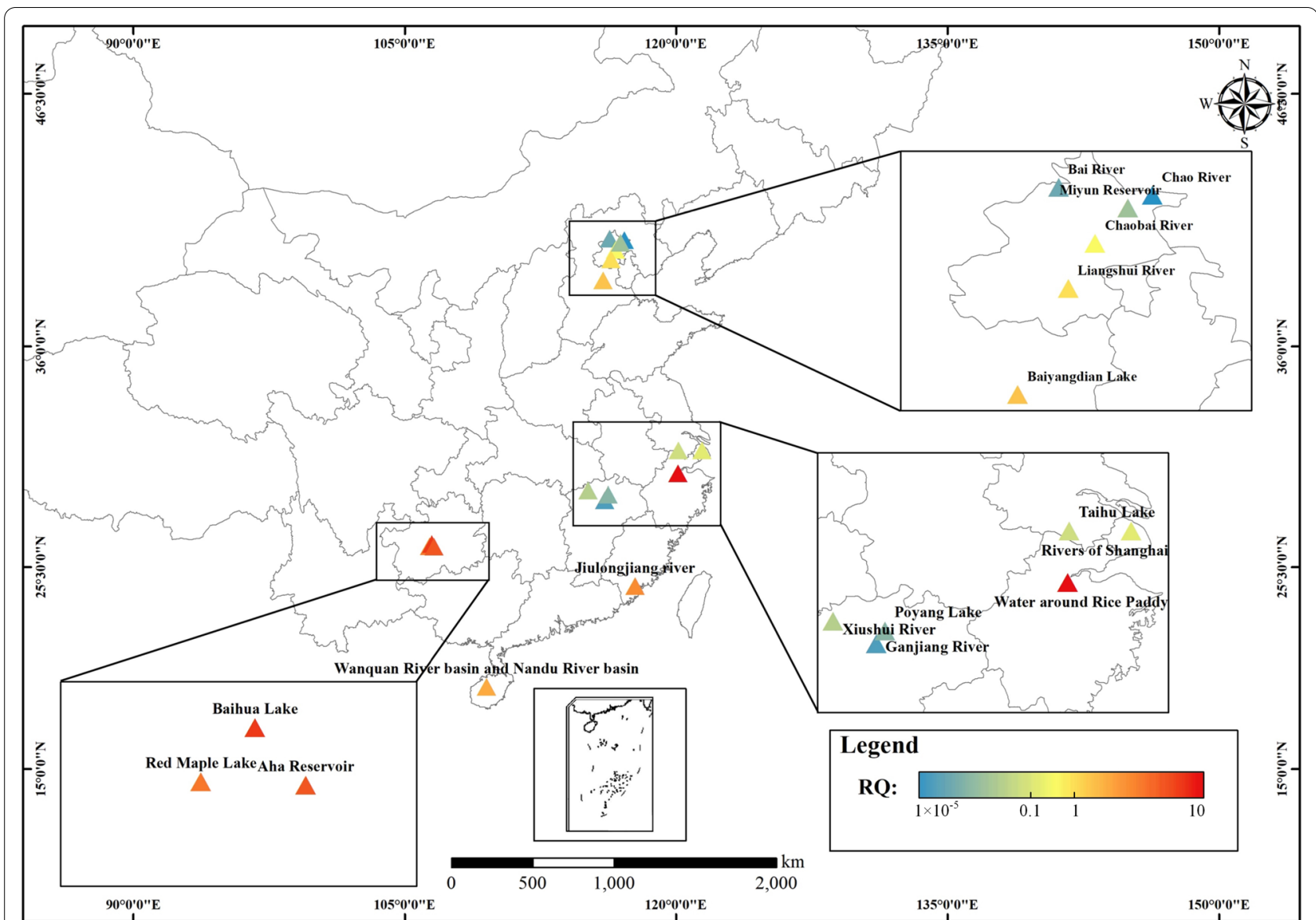

Fig. 6 Distribution of maximum risk quotient (RQ) for triadimefon in some Chinese rivers and reservoirs; risk value is represented by different colors. $\mathrm{RQ}<0.1$ represents insignificant risk, $0.1 \leq \mathrm{RQ}<1$ represents low risk, and $1 \leq \mathrm{RQ}<10$ represents moderate risk

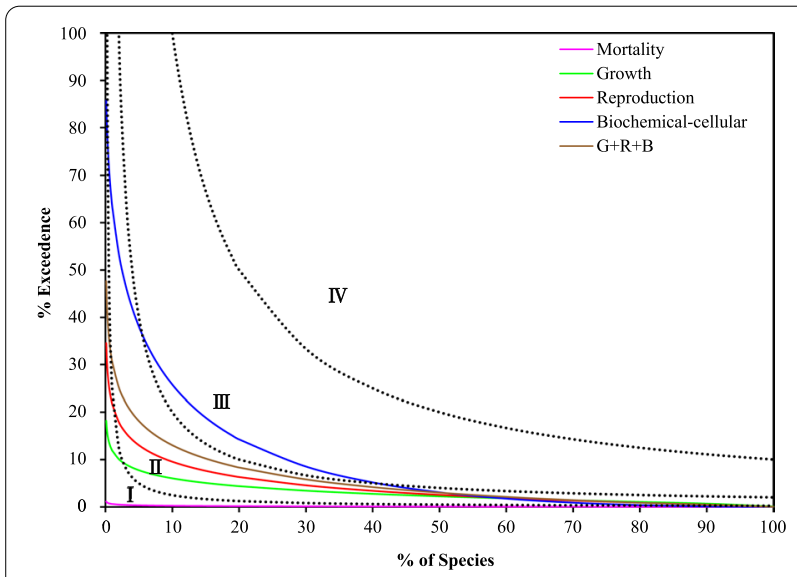

Fig. 7 Joint probability curves for ecological risk of triadimefon in surface waters from China. Different colors represent JPCs constructed for various assessment end points based on toxic effects. Roman numerals indicate regions delineated by black dotted lines represent the four levels of risk categorization: I: de-minimis, II: Iow, III: intermediate, IV: high. $G+R+B$ indicates the second screening of the data for growth and development, reproduction, and biochemical effects and $\mathrm{G}+\mathrm{R}+\mathrm{B}$ were characterized as "low", while risks based on biochemical-cellular effects was classified as "intermediate". The probability that reproduction of $5 \%$ of aquatic organisms in surface water in China would be affected by the current concentrations of triadimefon was close to $15 \%$. The results of risk assessment about triadimefon were consistent with conclusions of previous studies [24]. The low risk was represented in the studies of Sun et al. [98] and Zhou et al. [99]. Since data of exposure and toxicity effect are limited, risk assessments of triadimefon on aquatic environments determined here were uncertain. Triadimefon might have certain risks to aquatic organisms and even aquatic biological population and aquatic ecosystems. Much work about concentration surveys is needed especially water bodies near agriculture land. According to previous surveys, the water bodies near agriculture land might have higher concentration of triadimefon than water bodies far from land of much triadimefon use. 


\section{Conclusions and perspectives}

Environmental exposure, migration, and transformation in the environment, bioaccumulation and metabolism in organisms, and effects on and toxic potencies to organisms of triadimefon were reviewed. Risks posed by triadimefon in various aquatic environments were assessed based on both semi-probabilistic and fully probabilistic approaches, in which RQ and JPCs were used, respectively. The main conclusions are as follows: (1) triadimefon is ubiquitous in surface waters with high rate of detection at relatively low limits of quantification; (2) abiotic degradation of triadimefon via hydrolysis and photolysis is affected by multiple factors, including $\mathrm{pH}$, temperature, solvent, and radiation wavelength; (3) stereoselectivity during biotic degradation of triadimefon occurs in soil and during transformation by organisms; (4) different enantiomers might be biotransformation and degraded differentially and cause multiple effects via various mechanisms. Although triadimefon has potential for enrichment, its enrichment capacity is relatively small, but enrichment of its metabolite triadimenol might be more significant; (5) toxic effects of triadimefon on aquatic organisms, especially on reproduction, is a key assessment end point that cannot be ignored; (6) the risk of triadimefon based on JPCs is rated low or intermediate risk based on different end points. Studies of the effects of triadimefon have focused primarily on amphibians and fish, and then there are relatively few studies on invertebrates, which need to be investigated more comprehensively. The metabolite of triadimefon, triadimenol, might have greater toxic potency than triadimefon. Few studies have considered the chiral nature of triadimefon and its transformation products. Toxic effects of triadimefon and its chiral monomers are also required to be considered when assessing the risks of triadimefon. Due to its reproductive toxicity, triadimefon may cause harm at the population level or even at the ecosystem level. Ecological risk assessment on the higher level should be taken into account. Although the toxicity and risk of triadimefon were determined to be low, measurements of exposure in various aquatic environments are limited especially in areas outside of China. Studies of triadimefon in China have focused primarily in the Beijing-Tianjin-Hebei and Yangtze River Delta regions, while the data of other regions where agricultural production is greater and triadimefon might be more applied such as northwest and northeast China are still limited. Currently, there is not relevant surface water environmental quality standard for triadimefon, so it is suggested to strengthen regulations to control the potential effects of triadimefon and its transformation products.
Abbreviations

US EPA: U.S. Environmental Protection Agency; EU: European Union; WWF: World Wide Fund for Nature and World Wildlife Fund; HQs: Hazard quotients; PPCPS: Pharmaceutical and personal care products; R-TDF: R- (-)-Triadimefon; S-TDF: S- (+)-Triadimefon; RR-TDN: 1R,2R- (-)-Triadimenol; RS-TDN: 1R,2S(-)-Triadimenol; SR-TDN: 1S,2R-(+)-Triadimenol; SS-TDN: 1S,2S- (+)-Triadimenol; BCF: Bioconcentration factor; BMF: Biomagnification; BAF: Bioaccumulation factor; HPT: Hypothalamic-pituitary-thyroid; HGC: Hatching gland cells; VTG: Vitellogenin; $E_{2}$ : Estradiol; ER: Estrogen receptor; AR: Androgen receptor; Deio2: Deiodinase; MDA: Malondialdehyde; TSH: Thyroid-stimulating hormone; tg: Thyroglobulin; TR: Thyroid receptor; T4: Thyroxine; thl: Tyrosine hydroxylase 1; dat: Dopamine transporter; vtg: Vitellogenin gene; SSD: Species sensitivity distribution; A-D: Anderson-Darling; $\mathrm{HC}_{5}$. Hazardous concentration for $5 \%$ species affected; K-S: Kolmogorov-Smirnov; PNEC: Predicted no-effect concentration; $\mathrm{RQ}$ : Risk quotient; JPC: Joint probability curve; PCR: Polymerase chain reaction.

\section{Supplementary Information}

The online version contains supplementary material available at https://doi. org/10.1186/s12302-022-00590-7.

Additional file 1. Data on exposure to triadimefon, expressed as concentrations in surface waters including rivers, lakes, reservoirs were collected from literature published in China and abroad and unpublished data from recent monitoring results by the authors (Table S1 and Table S2). Data on half-lives to triadimefon were also collected from literature published in China and abroad (Table S3). Toxicity data for the triadimefon were collected from the ECOTOX Knowledgebase developed by US EPA (https:// cfpub.epa.gov/ecotox/search.cfm), following the principles of accuracy, relevance and reliability (Table $\mathbf{S 4}$ ). Toxicity data based on various assessment end points sets for triadimefon were tested for normality by use of Anderson-Darling text, $\mathrm{HC}_{5}$ and PNEC were derived by curves fitting (Table S5). Finally, sensitivity distributions base on different end points were compared by use of the two-sample Kolmogorov-Smirnov test, using the SPSS software version 26 (Table S6). ECOTOX Knowledgebase. https://cfpub.epa.gov/ecotox/search.cfm Accessed 20 April 2021.

\section{Acknowledgements}

This study was supported by the National Natural Science Foundation of China $(41977364,41807400)$. Prof. Jin was supported by the "Beijing outstanding talent training program". Prof. Giesy was supported by the "High Level Foreign Experts" program (\#GDT20143200016) funded by the State Administration of Foreign Experts Affairs, the P.R. China to Nanjing University and the Einstein Professor Program of the Chinese Academy of Sciences. He was also supported by the Canada Research Chair program and a Distinguished Visiting Professorship in the Department of Environmental Sciences at Baylor University, Waco, Texas, USA.

\section{Authors' contributions}

$X J$ and $J X$ contributed to the study conception and design. The literature search and analysis were performed by $L H, Y L, Z Y, H X$, and $Y L$. NL provided preliminary basis research. $Y L$ and $M C$ provided the information of exposure data, and LH drafted the work. The manuscript was improved and critically revised by JPG, XJ, JX, and FW. JPG also modified the language. All authors commented on previous versions of the manuscript. All authors read and approved the final manuscript.

\section{Funding}

This study was supported by the National Natural Science Foundation of China $(41977364,41807400)$.

\section{Availability of data and materials}

The datasets used and analyzed during the current study are available from the corresponding author on reasonable request. 


\section{Declarations}

Ethics approval and consent to participate Not applicable.

\section{Consent for publication}

Not applicable.

\section{Competing interests}

The authors declare that they have no competing interests.

\section{Author details}

${ }^{1}$ State Key Laboratory of Environmental Criteria and Risk Assessment, Chinese Research Academy of Environmental Sciences, Beijing 100012, China. ${ }^{2}$ China National Environmental Monitoring Centre, Beijing 100012, China. ${ }^{3}$ Department of Veterinary Biomedical Sciences and Toxicology Centre, University of Saskatchewan, Saskatoon, SK, Canada. ${ }^{4}$ Department of Environmental Sciences, Baylor University, Waco, TX, USA. ${ }^{5}$ Department of Zoology and Center for Integrative Toxicology, Michigan State University, East Lansing, MI 48824, USA.

Received: 8 November 2021 Accepted: 4 January 2022 Published online: 21 January 2022

\section{References}

1. Zhou ZY, Li CC, Gao TC, Tan GJ (2008) Research progress of triazole fungicides. J Anhui Agric Sci 36:11842-11844. https://doi.org/10.3969/j.issn. 0517-6611.2008.27.099

2. Gao HY (2014) Adsorption of triadimefon in water with cationic-nonionic organobentonite. Water Purif Technol 33:42-45

3. Wei C, Song LJ, Yang WP, Lu TY, Wang P, Yao XM (2016) Detection and feature analysis of organochlorine pesticide pollution in drinking water sources in Guiyang. Environ Sci Technol 39(3):131-135

4. US EPA (2006) Registration eligibility decision for triadimefon and tolerance reassessment for traidmimenol. Washington

5. Liu Y, Yang WP, Wei CH, Lu TY, Song LJ (2015) Pesticide contamination characteristics and health risks of drinking water sources in Guiyang during dry season. Earth Environ 43(6):653-659. https://doi.org/10.14050/j. cnki.1672-9250.2015.06.008

6. Liu N, Jin XW, Xue LD, Shi JZ, Xu YJ (2017) Concentrations distribution and ecological risk assessment of pharmaceuticals and personal care products in Taihu Lake. China Environ Sci 37:3515-3522

7. You MH (2008) Determination and abiotic degradation of nine trizole pesticides in natual aquatic environments. Xiamen University

8. Fu Y, Yang T, Zhao J, Zhang L, Chen RX, Wu YL (2017) Determination of eight pesticides in Lycium barbarum by LC-MS/MS and dietary risk assessment. Food Chem 218:192-198. https://doi.org/10.1016/j.foodc hem.2016.09.014

9. OEHHA (2017) Proposition 65: a list of chemicals known to the state to cause cancer or reproductive toxicity [EB/OL]

10. Pan UK (2005) A catalogue of lists of pesticides identifying those associated with particularly harmful health or environmental impacts. Brighton

11. Jiang JH, Hu GJ, Zhang CP, Zhao XP, Wang Q, Chen LZ (2017) Toxicological analysis of triadimefon on endocrine disruption and oxidative stress during rare minnow (Gobiocypris rarus) larvae development. Environ Sci Pollut Res 24:26681-26691. https://doi.org/10.1007/s11356-017-0317-3

12. Li M, Li SY, Yao TT, Zhao RJ, Wang QW, Zhu GN (2016) Waterborne exposure to triadimefon causes thyroid endocrine disruption and developmental delay in Xenopus laevis tadpoles. Aquat Toxicol 177:190-197. https://doi.org/10.1016/j.aquatox.2016.05.018

13. Wu SG, Hu GJ, Zhao XP, Wang Q, Jiang JH (2018) Synergistic potential of fenvalerate and triadimefon on endocrine disruption and oxidative stress during rare minnow embryo development. Environ Toxicol 33:759-769. https://doi.org/10.1002/tox.22563

14. Zhang WJ, Deng Y, Chen L, Zhang LY, Wang ZK, Liu R, Diao JL, Zhou ZQ (2020) Effect of triadimefon and its metabolite on adult amphibians Xenopus laevis. Chemosphere 243:125288. https://doi.org/10.1016/j.chemo sphere.2019.125288
15. Zhang WJ, Deng Y, Chen L, Zhang LY, Wang ZK, Liu R, Zhou ZQ, Diao JL (2020) Comparing the effect of triadimefon and its metabolite on male and female Xenopus laevis: Obstructed growth and gonad morphology. Chemosphere 259:127415. https://doi.org/10.1016/j.chemosphere.2020. 127415

16. De la Paz JF, Beiza N, Paredes-Zuniga S, Hoare MS, Allende ML (2017) Triazole fungicides inhibit zebrafish hatching by blocking the secretory function of hatching gland cells. Int J Mol Sci 18(4):710. https://doi.org/ 10.3390/ijms18040710

17. Hassold E, Backhaus T (2009) Chronic toixicity of five structurally diverse demethylase-inhibiting fungicides to the crustacean Daphnia magna: a comparative assessmentive. Environ Toxicol Chem 28:1218-1226. https:// doi.org/10.1897/08-339.1

18. Paredes-Zuniga S, Trost N, De la Paz JF, Alcayaga J, Allende ML (2019) Behavioral effects of triadimefon in zebrafish are associated with alterations of the dopaminergic and serotonergic pathways. Prog Neuropsychopharmacol Biol Psychiatry 92:118-126. https://doi.org/10.1016/j. pnpbp.2018.12.012

19. Ward WO, Delker DA, Hester SD, Thai SF, Wolf DC, Allen JW, Nesnow S (2006) Transcriptional profiles in liver from mice treated with hepatotumorigenic and nonhepatotumorigenic triazole conazole fungicides: propiconazole, triadimefon, and myclobutanil. Toxicol Pathol 34:863-878. https://doi.org/10.1080/01926230601047832

20. Liu HC, Chu TY, Chen LL, Gui WJ, Zhu GN (2017) The cardiovascular toxicity of triadimefon in early life stage of zebrafish and potential implications to human health. Environ Pollut 231:1093-1103. https://doi.org/10.1016/j. envpol.2017.05.072

21. Menegola E, Broccia RF, Prati M, Giavini E (2000) In vitro teratogenic potential of two antifungal triazoles: triadimefon and triadimenol. In Vitro Cell Dev Biol Animal 36:89-95. https://doi.org/10.1290/1071-2690(2000) 036\%3c0088:IVTPOT\%3e2.0.CO:2

22. Maria Z, Kyriaki M (2017) Zebrafish as an alternative vertebrate model for investigating developmental toxicity-the triadimefon example. Int J Mol Sci 18(4):817. https://doi.org/10.3390/ijms18040817

23. Ma YN, Sun LH, Li SY, Ni YX, Cao ZY, Chen MX, Mou RX (2020) Modulation of steroid metabolism and xenobiotic biotransformation responses in zebrafish (Danio rerio) exposed to triadimefon. Environ Pollut 262:114145. https://doi.org/10.1016/j.envpol.2020.114145

24. Liu N, Jin XW, Zhou JY, Wang YY, Yang Q, Wu FC, Giesy JP, Johnson AC (2018) Predicted no-effect concentration (PNEC) and assessment of risk for the fungicide, triadimefon based on reproductive fitness of aquatic organisms. Chemosphere 207:682-689. https://doi.org/10.1016/j.chemo sphere.2018.05.093

25. Zhang WG, Gao JS, Chen SS, Li CJ (2005) Determination of residual triadimefon, triadimenol-a, triadimenol-b in corn by gel permeation chromatography and gas chromatography/mass spectrometry. Chin J Anal Chem 33:1442-1444. https://doi.org/10.2116/bunsekikagaku.54.1015

26. Watschke TL, Mumma RO, Linde DT, Borger JA and Harrison SA (2000) Surface runoff of selected pesticides applied to turfgrasses In: JM Clark and MP Kenna (eds.). Fate and management of turfgrass chemicals. Acs Symposium Series 743:94-105

27. Thomatou AA, Zacharias I, Hela D, Konstantinou I (2013) Determination and risk assessment of pesticide residues in lake Amvrakia (Western Greece) after agricultural land use changes in the lake's drainage basin. Int J Environ Anal Chem 93:780-799. https://doi.org/10.1080/03067319. 2012.656099

28. Stamatis N, Hela D, Triantafyllidis V, Konstantinou I (2013) Spatiotemporal variation and risk assessment of pesticides in water of the lower catchment basin of Acheloos River, Western Greece. Sci World J. https://doi. org/10.1155/2013/231610

29. Liu N, Jin XW, Feng CL, Wang ZJ, Wu FC, Johnson AC, Xiao HX, Hollert H, Giesy JP (2020) Ecological risk assessment of fifty pharmaceuticals and personal care products (PPCPs) in Chinese surface waters: a proposed multiple-level system. Environ Int 136:105454. https://doi.org/10.1016/j. envint.2019.105454

30. Liu N, Jin XW, Yan Z, Luo Y, Feng CL, Fu ZY, Tang Z, Wu FC, Giesy JP (2020) Occurrence and multiple-level ecological risk assessment of pharmaceuticals and personal care products (PPCPs) in two shallow lakes of China. Environ Sci Eur 32:69. https://doi.org/10.1186/s12302-020-00346-1 
31. Stamatis N, Hela D, Konstantinou I (2010) Occurrence and removal of fungicides in municipal sewage treatment plant. J Hazard Mater 175:829-835. https://doi.org/10.1016/j.jhazmat.2009.10.084

32. Garrison AW, Avants JK, Jones WJ (2011) Microbial transformation of triadimefon to triadimenol in soils: selective production rates of triadimenol stereoisomers affect exposure and risk. Environ Sci Technol 45:2186-2193. https://doi.org/10.1021/es103430s

33. Li ZY, Zhang YC, Li QL, Wang WX, Li JY (2011) Enantioselective degradation, abiotic racemization, and chiral transformation of triadimefon in soils. Environ Sci Technol 45:2797-2803. https://doi.org/10.1021/es103 $830 z$

34. Liu TT, Diao JL, Di SS, Zhou ZQ (2014) Stereoselective bioaccumulation and metabolite formation of triadimefon in Tubifex tubifex. Environ Sci Technol 48:6687-6693. https://doi.org/10.1021/es5000287

35. Wang ZK, Tian ZN, Chen L, Zhang WJ, Zhang LY, Li Y, Diao JL, Zhou ZQ (2020) Stereoselective metabolism and potential adverse effects of chiral fungicide triadimenol on Eremias argus. Environ Sci Pollut Res 27:78237834. https://doi.org/10.1007/s11356-019-07205-4

36. Xu P, Huang LD (2017) Stereoselective bioaccumulation, transformation, and toxicity of triadimefon in Scenedesmus obliquus. Chirality 29:61-69. https://doi.org/10.1002/chir.22671

37. Liu YH, Guo ZY, Yang RB, Xiong YQ (2004) Hydrolysis dynamic of triadimefon in aquatic environment. J Agro-Environ Sci 23(6):1133-1135. https:// doi.org/10.3321/j.issn:1672-2043.2004.06.023

38. Liu YH, Guo ZY, Yang RB, Xiong YQ (2005) Hydrolysis dynamics of triadimefon in aquatic environment different in $\mathrm{pH}$ value. Rural Eco-Environ 21(67-68):71. https://doi.org/10.3969/j.issn.1673-4831.2005.01.016

39. Liu YH (2005) Chemistry behavior of triadimefon in aquatic environment. Hunan Agricultural University

40. Da Silva JP, Ferreira LFV, Da Silva AM (2003) Aqueous photochemistry of pesticides triadimefon and triadimenol. J Photochem Photobiol, A 154:293-298. https://doi.org/10.1016/s1010-6030(02)00328-3

41. lesce MR, Graziano ML, Cermola F, Montella S, di Gioia L, Stasio C (2003) Effects of sensitizers on the photodegradation of the systemic fungicide triadimenol. Chemosphere 51:163-166. https://doi.org/10.1016/s00456535(02)00823-8

42. Da Silva JP, Da Silva AM, Khmelinskii IV, Martinho JMG, Ferreira LFV (2001) Photophysics and photochemistry of azole fungicides: triadimefon and triadimenol. J Photochem Photobiol, A 142:31-37. https://doi.org/10. 1016/s1010-6030(01)00489-0

43. Dureja P, Subir KN (1997) Photodegradation of azole fungicide triadimefon. J Agric Food Chem 45:294-198. https://doi.org/10.1021/jf960074n

44. Singh N (2005) Factors affecting triadimefon degradation in soils. J Agric Food Chem 53:70-75. https://doi.org/10.1021/jf048884j

45. Mohamed AT, Yang ZH, Li JH, Zhao Y, Alrasheed Mohamed Omer S, Xiong YB (2018) The influence of microbial communities for triadimefon enantiomerization in soils with different pH values. Chirality 30:293-301. https:// doi.org/10.1002/chir.22796

46. Khoury R, Geahchan A, Coste CM, Antoun MA, Kawar NS (2001) Behavior of triadimefon in two Lebanese soils. J Environ Sci Health B 36:741-754. https://doi.org/10.1081/PFC-100107408

47. Liu HC, Shao JL, Su J, Wang ZF, Li QW (2013) Degradation kinetics of triadimefon in facility soil. Soil Sci 44(01):128-131. https://doi.org/10. 19336/j.cnki.trtb.2013.01.020

48. Nag SK, Dureja P (2003) Environmental transformation of triadimefon in water and on plant leaf surface. J Environ Sci Health B 38:49-57. https:// doi.org/10.1081/PFC-120016605

49. Liu HJ, Cai WD, Liu WP (2011) Enantioselective toxicity of chiral pesticides in aquatic systems chiral pesticides: stereoselectivity and its consequences. ACS Symp Ser 1085:107-120

50. Li JT, Wang YH, Li W, Xu P, Guo BY, Li JZ, Wang HL (2017) Tissue distribution and metabolism of triadimefon and triadimenol enantiomers in Chinese lizards (Eremias argus). Ecotoxicol Environ Safety 142:284-292. https://doi. org/10.1016/j.ecoenv.2017.04.035

51. Shen QX, Li JT, Xu P, Li W, Zhuang GQ, Wang YH (2017) Enantioselective metabolism of triadimefon and its chiral metabolite triadimenol in lizards. Ecotoxicol Environ Safety 143:159-165. https://doi.org/10.1016/j.ecoenv. 2017.05.024

52. Wang YH, Yu DY, Xu P, Guo BY, Zhang YF, Li JZ, Wang HL (2014) Stereoselective metabolism, distribution, and bioaccumulation brof triadimefon and triadimenol in lizards. Ecotoxicol Environ Safety 107:276-283. https:// doi.org/10.1016/j.ecoenv.2014.06.021

53. Konwick BJ, Garrison AW, Avants JK, Fisk AT (2006) Bioaccumulation and biotransformation of chiral triazole fungicides in rainbow trout (Oncorhynchus mykiss). Aquat Toxicol 80:372-381. https://doi.org/10.1016/j. aquatox.2006.10.003

54. Kenneke JF, Ekman DR, Mazur CS, Konwick BJ, Fisk AT, Avants JK, Garrison AW (2010) Integration of metabolomics and in vitro metabolism assays for investigating the stereoselective transformation of triadimefon in rainbow trout. Chirality 22:183-192. https://doi.org/10.1002/chir.20725

55. Li YB, Dong FS, Liu XG, Jun Xu, Han YT, Zheng YQ (2014) Chiral fungicide triadimefon and triadimenol: stereoselective transformation in greenhouse crops and soil, and toxicity to Daphnia magna. J Hazard Mater 265:115-123. https://doi.org/10.1016/j.jhazmat.2013.11.055

56. Zarn JA, Bruschweiler BJ, Schlatter JR (2003) Azole fungicides affect mammalian steroidogenesis by inhibiting sterol 14 alpha-demethylase and aromatase. Environ Health Perspect 111:255-261. https://doi.org/10. 1289/ehp.5785

57. Barton HA, Tang J, Sey YM, Stanko JP, Murrell RN, Rockett JC, Dix DJ (2006) Metabolism of myclobutanil and triadimefon by human and rat cytochrome P450 enzymes and liver microsomes. Xenobiotica 36:793-806. https://doi.org/10.1080/00498250600821292

58. Crowell SR, Henderson WM, Fisher JW, Kenneke JF (2010) Gender and species differences in triadimefon metabolism by rodent hepatic microsomes. Toxicol Lett 193:101-107. https://doi.org/10.1016/j.toxlet.2009.12. 011

59. Kenneke JF, Mazur CS, Ritger SE, SackTJ (2008) Mechanistic investigation of the noncytochrome P450-mediated metabolism of triadimefon to triadimenol in hepatic microsomes. Chem Res Toxicol 21:1997-2004. https://doi.org/10.1021/tx800211t

60. Aladaghlo Z, Fakhari AR, Alavioon SI, Dabiri M (2019) Ultrasound assisted dispersive solid phase extraction of triazole fungicides by using an $\mathrm{N}$-heterocyclic carbene copper complex supported on ionic liquidmodified graphene oxide as a sorbent. Microchim Acta. https://doi.org/ 10.1007/s00604-019-3276-1

61. Shen J (2013) The toxicity and bio-concentration of three pesticides to benthic animals molluscs. Zhejing University

62. Papis E, Bernardini G, Gornati R, Prati M (2006) Triadimefon causes branchial arch malformations in Xenopus laevis embryos. Environ Sci Pollut Res 13:251-255. https://doi.org/10.1065/espr2006.01.014

63. Cao CY, Wang QW, Jiao F, Zhu GN (2016) Impact of co-exposure with butachlor and triadimefon on thyroid endocrine system in larval zebrafish. Exp Toxicol Pathol 68:463-469. https://doi.org/10.1016/j.etp. 2016.07.004

64. Le TTY, Peijnenburg WJGM (2013) Modeling toxicity of mixtures of perfluorooctanoic acid and triazoles (triadimefon and paclobutrazol) to the benthic cladoceran Chydorus sphaericus. Environ Sci Technol 47:6621-6629. https://doi.org/10.1021/es4001104

65. Liu SY, Jin Q, Huang XH, Zhu GN (2014) Disruption of zebrafish (Danio rerio) sexual development after full life-cycle exposure to environmental levels of triadimefon. Environ Toxicol Pharmacol 37:468-475. https://doi. org/10.1016/j.etap.2013.11.007

66. Zhang WJ, Lu YL, Huang LD, Cheng C, Di SS, Chen L, Zhou ZQ, Diao JL (2018) Comparison of triadimefon and its metabolite on acute toxicity and chronic effects during the early development of Rana nigromaculata tadpoles. Ecotoxicol Environ Safety 156:247-254. https://doi.org/10. 1016/j.ecoenv.2018.03.009

67. Liu SY, Chang JH, Zhao Y, Zhu GN (2011) Changes of thyroid hormone levels and related gene expression in zebrafish on early life stage exposure to triadimefon. Environ Toxicol Pharmacol 32:472-477. https://doi.org/10. 1016/j.etap.2011.09.002

68. Yu L, Chen ML, Liu YH, Gui WJ, Zhu GN (2013) Thyroid endocrine disruption in zebrafish larvae following exposure to hexaconazole and tebuconazole. Aquat Toxicol 138-139:35-42. https://doi.org/10.1016/j.aquat ox.2013.04.001

69. Jiang JH, Wu SG, Chen JB, Wu CX, Cai LM, Zhao XP (2015) Acute toxic effects of triadimefon on different life stages of Zebrafish (Danio rerio) and Chinese Rare Minnow (Gobiocypris rarus). Asian J Ecotoxicol 10:150-156

70. Zhu B, Liu L, Gong YX, Ling F, Wang GX (2014) Triazole-induced toxicity in developing rare minnow (Gobiocypris rarus) embryos. Environ Sci Pollut Res 21:13625-13635. https://doi.org/10.1007/s11356-014-3317-6 
71. Rodriguez EM, Medesani DA, Fingerman M (2007) Endocrine disruption in crustaceans due to pollutants: a review. Comp Biochem Physiol A: Mol Integr Physiol 146:661-671. https://doi.org/10.1016/j.cbpa.2006.04.030

72. Li JT, Chang J, Li W, Guo BY, Li JZ, Wang HL (2017) Disruption of sexhormone levels and steroidogenic-related gene expression on Mongolia Racerunner (Eremias argus) after exposure to triadimefon and its enantiomers. Chemosphere 171:554-563. https://doi.org/10.1016/j.chemo sphere.2016.12.096

73. Groppelli S, Pennati R, De Bernardi F, Menegola E, Giavini E, Sotgia C (2005) Teratogenic effects of two antifungal triazoles, triadimefon and triadimenol, on Xenopus laevis development: craniofacial defects. Aquat Toxicol 73:370-381. https://doi.org/10.1016/j.aquatox.2005.04.004

74. Di Renzo F, Broccia ML, Giavini E, Menegola E (2007) Antifungal triazole derivative triadimefon induces ectopic maxillary cartilage by altering the morphogenesis of the first branchial arch. Birth Defects Res B 80:2-11. https://doi.org/10.1002/bdrb.20097

75. Di Renzo F, Broccia ML, Giavini E, Menegola E (2011) Stage-dependent abnormalities induced by the fungicide triadimefon in the mouse. Reprod Toxicol 31:194-199. https://doi.org/10.1016/j.reprotox.2010.10. 011

76. Menegola E, Broccia ML, Di Renzo F, Massa V, Giavini E (2005) Craniofacial and axial skeletal defects induced by the fungicide triadimefon in the mouse. Birth Defects Res B 74:185-195. https://doi.org/10.1002/bdrb. 20035

77. Pennati R, Groppelli S, Zega G, Biggiogero M, De Bernardi F, Sotgia C (2006) Toxic effects of two pesticides, Imazalil and Triadimefon, on the early development of the ascidian Phallusia mammillata (Chordata, Ascidiacea). Aquat Toxicol 79:205-212. https://doi.org/10.1016/j.aquatox. 2006.05.012

78. Wolf DC, Allen JW, George MH, Hester SD, Sun GB, Moore T, Thai SF, Delker D, Winkfield E, Leavitt S, Nelson G, Roop BC, Jones C, Thibodeaux J, Nesnow S (2006) Toxicity profiles in rats treated with tumorigenic and nontumorigenic triazole conazole fungicides: propiconazole, triadimefon, and myclobutanil. Toxicol Pathol 34:895-902. https://doi.org/10.1080/ 01926230601047808

79. Li W, Zha JM, Li ZL, Yang LH, Wang ZJ (2009) Effects of exposure to acetochlor on the expression of thyroid hormone related genes in larval and adult rare minnow (Gobiocypris rarus). Aquat Toxicol 94:87-93. https://doi. org/10.1016/j.aquatox.2009.06.002

80. Walker QD, Lewis MH, Crofton KM, Mailman RB (1990) Triadimefon, a triazole fungicide, induces stereotyped behavior and alters monoamine metabolism in rats. Toxicol Appl Pharmacol 102:474-485. https://doi.org/ 10.1016/0041-008x(90)90043-t

81. Liu SY (2011) Embryonic developmental and endocrine-reproductive toxicity of triadimefon on zebrafish. Zhejiang University

82. Gagnaire F, Micillino JC (2006) Effects of triadimefon on extracellular dopamine, DOPAC, HVA and 5-HIAA in adult rat striatum. Toxicology 217:91-104. https://doi.org/10.1016/j.tox.2005.08.021

83. Walker QD, Mailman RB (1996) Triadimefon and triadimenol: effects on monoamine uptake and release. Toxicol Appl Pharmacol 139:227-233. https://doi.org/10.1006/taap.1996.0161

84. Sozen H, Celik OI, Cetin ES, Yilmaz N, Aksozek A, Topal Y, Cigerci IH, Beydilli $H(2015)$ Evaluation of the protective effect of silibinin in rats with liver damage caused by itraconazole. Cell Biochem Biophys 71:1215-1223. https://doi.org/10.1007/s12013-014-0331-8

85. Sun RJ, Guo J, Song QQ, Song WH (2013) Study on the toxicity of triadimefon and triadimenol to human hepatocytes. Acta Scientiarum Naturalium Universitatis Nankaiensis 46(01):85-90

86. Petit F, Le Goff P, Cravedi JP, Valotaire Y, Pakdel F (1997) Two complementary bioassays for screening the estrogenic potency of xenobiotics: recombinant yeast for trout estrogen receptor and trout hepatocyte cultures. J Mol Endocrinol 19:321-335. https://doi.org/10.1677/jme.0. 0190321

87. Liu N (2016) Study for reproductive toxicity effect and ecological risk assessment of typical PPCPs China. University of Geosciences

88. Wang $Y H, X u C$, Wang D, Weng HB, Yang GL, Guo DM, Yu RX, Wang XQ Wang Q (2020) Combined toxic effects of fludioxonil and triadimefon on embryonic development of zebrafish (Danio rerio). Environ Pollut 260:114105. https://doi.org/10.1016/j.envpol.2020.114105
89. European Commission (EC) (2003) Technical guidance document on risk assessment, Joint Research Centre, Institute for Health and Comsumer Protection, European Chemicals Bureau, Ispra, Italy

90. Bu Q, Wang B, Huang J, Deng SB, Yu G (2013) Pharmaceuticals and personal care products in the aquatic environment in China: a review. J Hazard Mater 262:189-211. https://doi.org/10.1016/j.jhazmat.2013.08.040

91. Aldenberg T, Jaworska JS (2000) Uncertainty of the hazardous concentration and fraction affected for normal species sensitivity distributions. Ecotoxicol Environ Saf 46:1-18. https://doi.org/10.1006/eesa.1999.1869

92. Han WH, Zao Y, Dang JH, Xiong L (2017) Distribution and ecological risk evaluation of phthalate esters in Fenhe River Basin. Environ Chem 36:1377-1387

93. Solomon KR, Baker DB, Richards RP, Dixon KR, Klaine SJ, Point TWL (1996) Ecological risk assessment of atrazine in North American surface waters. Environ Toxicol Chem 15:31-76. https://doi.org/10.1002/etc.5620150105

94. Solomon K, Giesy JP, Jones P (2000) Probabilistic risk assessment of agrochemicals in the environment. Crop Prot 19(8):649-655. https://doi.org/ 10.1016/S0261-2194(00)00086-7

95. Sun HW, Giesy JP, Jin XW, Wang J (2017) Tiered probabilistic assessment of organohalogen compounds in the Han River and Danjiangkou Reservoir, Central China. Sci Total Environ 586:163-173. https://doi.org/10.1016/j. scitotenv.2017.01.194

96. Liu N, Wang YY, Yang Q, Lu YB, Jin XW, Giesy JP, Johnson AC (2016) Probabilistic assessment of risks of diethylhexyl phthalate (DEHP) in surface waters of China on reproduction of fish. Environ Pollut 213:482-488. https://doi.org/10.1016/j.envpol.2016.03.005

97. Moore DRJ, Teed RS, Greer CD, Solomon KR, Giesy JP (2014) Refined avian risk assessment for chlorpyrifos in the United States. Rev Environ Contam Toxicol 231:163-217. https://doi.org/10.1007/978-3-319-03865-0_6

98. Sun J, Xiao PF, Liu YH, Yin XH, Zhu GN (2020) Study on the effect of triadimefon on freshwater zooplankton community using indoor microcosm system. Asian J Ecotoxicol 15:139-148

99. Zhou YT, Wu JX, Wang B, Duan L, Zhang YZ, Zhao WX, Wang F, Sui Q, Chen ZY, Xu DJ, Li QX, Yu G (2020) Occurrence, source and ecotoxicological risk assessment of pesticides in surface water of Wujin District (northwest of Taihu Lake), China. Environ Pollut 265:114953. https://doi.org/10.1016/j. envpol.2020.114953

\section{Publisher's Note}

Springer Nature remains neutral with regard to jurisdictional claims in published maps and institutional affiliations.

\section{Submit your manuscript to a SpringerOpen ${ }^{\circ}$ journal and benefit from:}

- Convenient online submission

- Rigorous peer review

- Open access: articles freely available online

- High visibility within the field

- Retaining the copyright to your article

Submit your next manuscript at springeropen.com 